FEDERAL RESERVE BANK OF SAN FRANCISCO

WORKING PAPER SERIES

\title{
De-leveraging or De-risking? How Banks Cope with Loss
}

\author{
Rhys M. Bidder and Adam H. Shapiro \\ Federal Reserve Bank of San Francisco \\ John R. Krainer \\ Board of Governors of the Federal Reserve System \\ December 2019 \\ Working Paper 2017-03 \\ http://www.frbsf.org/economic-research/publications/working-papers/2017/03/
}

\section{Suggested citation:}

Bidder, Rhys M., John R. Krainer, Adam H. Shapiro. 2019. "De-leveraging or de-risking? How banks cope with loss,” Federal Reserve Bank of San Francisco Working Paper 2017-03. https://doi.org/10.24148/wp2017-03

The views in this paper are solely the responsibility of the authors and should not be interpreted as reflecting the views of the Federal Reserve Bank of San Francisco or the Board of Governors of the Federal Reserve System. 


\title{
De-leveraging or de-risking? How banks cope with loss
}

\author{
Rhys M. Bidder, John R. Krainer, Adam Hale Shapiro \\ Federal Reserve Bank of San Francisco and Board of Governors
}

\begin{abstract}
We use variation in banks' loan exposure to industries adversely affected by the oil price declines of 2014 to explore how they respond to a net worth shock. Using granular data obtained under the Fed's stress testing programs we show that exposed banks tightened credit on corporate lending and on mortgages that they would ultimately hold on their balance sheet. However, they expanded credit for mortgages to be securitized, particularly those that are government-backed. Thus, banks re-balance their portfolio so as to lower their average risk weight, rather than scaling back the size of their balance sheet, as looking at on-balance-sheet corporate or residential lending alone would suggest. These results show the importance of taking a cross-balance sheet perspective when examining bank behavior. In addition, in terms of the ultimate 'credit channel' to firms and households, we show precisely how borrowers substitute to alternative financing when banks they initially borrow from tighten credit. In showing that there was ultimately a minimal impact on borrowers' overall funding, we provide a benchmark for crisis-period studies, which typically find a powerful credit channel effect.
\end{abstract}

\footnotetext{
${ }^{\text {th }}$ Disclaimer: The views expressed in this document and all errors and omissions should be regarded as those of the authors and not necessarily those of the Federal Reserve Bank of San Francisco, the Federal Reserve Board of Governors, or the Federal Reserve System. This paper has been screened to ensure that no confidential bank or firm-level data have been revealed. We thank Tesia Chuderewicz for excellent research assistance and Anita Todd for editorial assistance. We also thank seminar participants at Cardiff University, Warwick University, Bank of England, ECB, Federal Reserve Board of Governors, University College London, Bay Area Finance Workshop, Fed System Micro Conference (esp., Mitchell Berlin), Chicago Fed, U.C. Davis, ES Asia (Hong Kong), Computing in Economics and Finance (NYC), CEBRA (esp. Victoria Nuguer), ES Europe (Lisbon), Fed System Energy Conference (esp. Christoffer Koch), the IAE Conference (esp. Bill Lang), the California Macroeconomic Conference (esp. Gary Richardson) and the BIS.

Email addresses: rhys.bidder@sf.frb.org (Rhys M. Bidder), john.r.krainer@frb.gov (John R. Krainer), adam.shapiro@sf.frb.org (Adam Hale Shapiro)
} 


\section{Introduction}

Banks solve complex optimization problems when choosing their portfolio. Consequently, when a bank suffers a shock its response can be expected to be multifaceted. Nevertheless, many canonical models of bank behavior simplify their problem to draw out broad intuitions. Perhaps the most prevalent intuition is that when a bank is damaged it will generally scale back its operations (Holmstrom and Tirole (1997)). Empirical studies inspired by this intuition have focused on a particular component of banks' loan books (typically corporate lending) and show that damaged banks cut credit supply. ${ }^{1}$

We investigate banks' responses to credit losses induced by the precipitous decline in oil prices of mid-2014 and show that the standard intuition above is incomplete. We take a cross-balance sheet approach, whereas much of the previous literature examines the 'bank lending channel' within a given asset class. ${ }^{2}$ We find that banks do not uniformly reduce credit supply following a damaging shock. Instead, while some types of credit are contracted, others are expanded. In particular, corporate loans and on-balance-sheet mortgages are reduced, while mortgages to be securitized and shifted off balance sheet are expanded. This pattern of adjustment entails a shift from heavily risk-weighted assets, against which banks must hold capital at a high rate, to lower risk-weighted assets. The effect on total lending, total size of the balance sheet, and the degree of leverage appears ambiguous. What is unambiguous, however, is a pattern of 'de-risking'. We observe banks making substantial reductions in their average risk weight rather than reducing their overall quantity of investments. We corroborate these empirical findings with survey evidence from the Senior Loan Officer Opinion Survey (SLOOS), which suggests that banks tightened terms of credit for the types of loans they wished to reduce (portfolio loans) and loosened credit for those they wished to attract (securitizable loans). Interestingly, we find little evidence that the de-risking across asset classes was mirrored by de-risking within an asset class.

The intuition that a bank might de-risk when damaged follows from basic portfolio theory. A shock to net worth may change the bank's effective risk tolerance as it is shifted closer to some type of funding constraint (see Froot and Stein (1998)). In this sense, a portfolio rebalancing reflects an updated solution to the risk-return tradeoff faced by the bank. One way a damaged bank can pull back is in terms of loan quantities - the traditional focus of the bank lending channel literature. De-risking can be thought of an alternative form of pulling back viewed from the broader portfolio perspective. We show that one can put the

\footnotetext{
${ }^{1}$ See Khwaja and Mian (2008), Ivashina and Scharfstein (2010), Jimenez, Ongena, Peydro, and Saurina (2012), and Chodorow-Reich (2014).

${ }^{2}$ This term was originally coined in the context of monetary policy transmission (Bernanke and Blinder (1992), Kashyap and Stein (1993) and Stein (1998)). It is now used more broadly and is based on the observation that because of externally imposed minimal capital ratios or constraints on bank leverage that emerge endogenously from information frictions, banks' net worth influences their asset choices.
} 
more traditional bank lending channel studies in a broader portfolio-level analysis and obtain important additional insights.

An additional contribution we make is to assess the ultimate impact of the oil shock on borrowers. We find no evidence of an operational 'credit channel' - the term typically given to the indirect effect of a shock on borrowers, via their banks. Specifically, borrowers who were more exposed to damaged banks do not appear to have made significant changes to their total loan balances or total assets after the shock. Since our data provide the identity of the borrowers, we can trace borrowers across banks, helping us to figure out why the effect is limited. The data reveal that borrowers facing worsening terms from exposed banks simply switched to other less-exposed banks within our sample.

The finding of a limited credit channel is in contrast to much of the credit channel literature that suggests such borrowers should be relatively harmed (see Khwaja and Mian (2008), Chodorow-Reich (2014), Acharya, Eisert, Eufinger, and Hirsch (2014), Huber (2018), Murfin (2012) for example). Related work has examined the credit channel during periods of stress for the broader financial system. ${ }^{3}$ While it is especially important to assess how the banking system functions in such crisis periods (where welfare losses may be more intense and where the role of policy is enhanced) it may also be the case that the strength or even the presence of the credit channel could depend on the crisis context. The availability of alternative financing from public debt and equity markets and other banks is likely very different from the normal period that we analyze. This study helps quantify the extent to which this is the case, providing a benchmark for papers that examine the effect of shocks in crisis periods. ${ }^{4}$

We use granular data from the FR Y-14 filings (Y14) obtained from bank holding companies as part of the Federal Reserve's Comprehensive Capital Analysis and Review (CCAR). This dataset includes a broader array of borrowers and loan types than those typically used in the banking literature, such as the Shared National Credits (SNC) data or Dealscan, and spans a wider range of asset classes. Information about specific loans held on the banks' balance sheets allows us to construct the exposure of the banks' corporate lending to firms in the oil and gas (O\&G) sector prior to the sudden decline in oil prices in 2014. Our treatment stems from exploiting variation in this variable across banks, which implicitly induced variation in the impact of the price decline on net worth.

For a variety of loan-types, we isolate the credit supply effects by using borrower fixed effects as in Khwaja and Mian (2008) which strips out possible credit demand effects. Any remaining endogeneity bias would arise from supply factors - specifically, factors associated with the banks' decision to hold O\&G loans. Our knowledge of the identities of the borrowers

\footnotetext{
${ }^{3}$ Chodorow-Reich (2014) examines the recent financial crisis and Acharya, Eisert, Eufinger, and Hirsch (2014) the European sovereign debt crisis, for example

${ }^{4}$ The importance of the availability of alternative financing also implies that studies based on less developed financial systems may not provide relevant insights to the U.S. system.
} 
and banks allows us to include a wide range of controls at the bank and bank-borrower level to address these concerns. These observable bank characteristics are not correlated with $\mathrm{O} \& \mathrm{G}$ exposure, indicating that high and low exposed banks appear similar on average. Additionally, we instrument our exposure variable with banks' branch locations from several years prior to the shock (similar to Gilje, Loutskina, and Strahan (2016)) with little change in our results. Overall, our results are robust to a variety of alternative exposure measures, standard error constructions, and permutation exercises.

\section{Relation to literature}

Banks' risk management has been studied both theoretically and empirically. Froot and Stein (1998) provide a theoretical framework motivating risk-management practices. In applied work, researchers have examined how banks adjust their risk profile in response to shocks. For example De Jonghe, Dewachter, Mulier, Ongena, and Schepens (2016) show that Belgian banks reallocated credit to less risky firms during the financial crisis. Liberti and Sturgess (2018) and Ongena, Peydro, and van Horen (2013) also suggest some tendency for corporate loan substitution after a shock, towards borrowers that are less risky in some sense. However, the key difference between our paper and these existing studies is that the latter show evidence of de-risking within asset classes. ${ }^{5}$ In contrast, we find that banks shift risk between asset classes, rotating their entire balance sheet away from high risk-weighted asset classes. In fact, we do not see much evidence of risk reallocation within the asset classes we consider. ${ }^{6}$

Our study touches on an existing literature that examines cross-balance sheet patterns. Using aggregate data Bernanke and Blinder (1992) show that banks shift from loans into securities after a shock. den Haan, Sumner, and Yamashiro (2007) also use aggregate data to assess responses to monetary policy shocks across banks' portfolios. Abbassi, Iyer, Peydro, and Tous (2016) use micro data on German banks to show that trading banks increase their holdings of securities whose prices had fallen during the financial crisis. However, they do not assess overall bank balance-sheet effects.

\footnotetext{
${ }^{5}$ We also note that De Jonghe, Dewachter, Mulier, Ongena, and Schepens (2016) exploit a crisis-era shock and restrict their analysis to banks and firms active in Belgium. Ongena, Peydro, and van Horen (2013) consider mainly small and medium-sized firms in Eastern Europe and Turkey, while Liberti and Sturgess (2018) are limited to data from a single multinational bank. As discussed below, our use of data from the especially important - and idiosyncratic - U.S. economy/banking system, post-crisis, provides an important addition to the literature, even when simply considering our data coverage.

${ }^{6}$ In a world where, increasingly, it is important to differentiate between risk weighted and total assets for regulatory purposes, our results provide important insights. Even outside explicit banking or regulatory literatures, the importance of distinguishing risk weighted and total assets is also now discussed (see Potter (2013) and Du, Tepper, and Verdelhan (2018), for example). See also Landier, Sraer, and Thesmar (2013), Drechsler, Savov, and Schnabl (2018) and Tella and Kurlat (2017) for analyses of bank risk management, though in this case focused on interest rate risk and its interaction with banking I/O issues.
} 
More closely related to our work are Chakraborty, Goldstein, and MacKinlay (2018) and Chakraborty, Goldstein, and MacKinlay (2019) (CGM). The former study looks at shocks that render mortgage lending more attractive and show that banks better placed to take advantage of of this opportunity were induced to make additional mortgage loans. Where the banks were more constrained in their ability to fund these loans, they freed up resources by making fewer commercial loans to firms. Thus, their paper documents an interesting form of 'crowding out' that suggests that banks face real constraints on raising funds to support new lending. In the latter study, the authors observe that banks particularly exposed to Fed policy increased mortgage origination following the Fed's MBS purchases, while also reducing their C\&I lending. The crowding out effect however, was not observed following Treasury purchases, suggesting a novel 'origination channel' (as they term it) rather than the typical 'bank lending channel'.?

While these studies feature cross-balance sheet effects, they differ from ours in important regards and our main contributions remain novel. Our paper considers a shock that, in the first instance, is to the bank whereas their impulses operate primarily as shocks to (the relative desirability of) an asset (mortgages). Ultimately both shocks have effects across the balance sheet but they are very different in nature and interpretation. ${ }^{8}$ The analysis in our study assesses what happens when a bank is damaged, taking as given the general attractiveness of assets. In this case, the cross balance sheet co-movements are not 'crowding out', but an attempt to de-risk. Indeed, the de-risking insights we obtain arise from the granular nature of our data and the fact that we observe off-balance sheet lending.

Our paper is also related to a number of studies that have assessed how banks change their asset liquidity following a shock. Cornett, McNutt, Strahan, and Tehranian (2011) find that banks that had relatively illiquid asset holdings at the start of the crisis were more prone to increase liquidity and reduce lending in response. Peek and Wilcox (2003) use data aggregated to the bank level to show the option to securitize mortgages helps stabilize mortgage lending over the business cycle. This is consistent with the work of Loutskina (2011) and Loutskina and Strahan (2009) who emphasize the increased liquidity of loans

\footnotetext{
${ }^{7}$ The Fed implemented its purchases through the to-be-announced (TBA) market so that origination of mortgages was particularly incentivized by the purchases - so responses are initiated by a particular class of asset being made more attractive, crowding out another class.

${ }^{8}$ As CGM themselves put it 'the shock to the bank is not a typical negative shock to capital, but rather a positive shock to the banks other lending opportunities that leads to substitution away from commercial loans'. Of course, it is possible that there are second-round net worth effects reflecting perhaps perception that the newly elicited lending is especially profitably, but those effects (if they exist) are an equilibrium result of the assumption that the banks pursue the new lending opportunities - thus they are derivative of fundamental shocks to assets and not to the bank, in the first instance. Furthermore, the Treasury purchases in ? somewhat surprisingly seem to have little impact through a pure net worth channel, in the absence of the 'origination channel that applies to mortgages/MBS. It is the idiosyncratic shock to a bank that renders, to an extent of each bank's particular treatment, certain assets more or less attractive.
} 
via securitization in recent years. Holding more liquid loans, it is suggested, attenuates the lending response to a shock under the standard bank lending channel and allows the banks to shift away from traditionally more liquid assets. Our results show that the net work shock induced a smaller effect on balance-sheet liquidity than it did on overall risk-weighted assets. ${ }^{9}$ The negligible effect on liquidity may be due to the fact that we are assessing a net worth shock as opposed to a liquidity shock, as is the case in these other studies.

We note that de-risking is not completely a priori obvious, despite it being consistent with theoretical models such as Froot and Stein (1998). Indeed, following the work of Jensen and Meckling (1976) (see also Stiglitz and Weiss (1981), Diamond (1989) and Acharya and Viswanathan (2011)) it is well understood that agency problems between creditors and borrowers can lead to 'risk shifting' behavior, whereby borrowers are incentivized to shift activities towards risky pursuits. This could particularly be the case after an adverse shock that drives a bank closer to default. Our paper confirms that, as one might have expected, at the comfortably capitalized levels of banks in 2014 our shock, while painful, did not cause sufficient damage for the risk-shifting effect to predominate. ${ }^{10}$ Rampini, Viswanathan, and Vuillemey (2017) also note that degradation of net worth can also hinder risk reductions by intermediaries by limiting their ability to hedge if hedging is also subject to financial constraints and Laeven and Levine (2009) note the effect of capital requirements on risk taking is in some contexts ambiguous and may depend on bank corporate structure.

Our results on banks' changing of their risk (weight) profile in response to the shock provide an important extension to the traditional empirical literature testing for the importance of net worth, as predicted by financial frictions models. While the cross-balance sheet aspect of our analysis takes us beyond the standard 'bank lending channel' literature, our work does include analyses of bank lending. As such, for our corporate and mortgage loan analysis, we implement the fixed-effects identification approach taken by Khwaja and Mian (2008) (KM). Recent papers that use the KM technique include: Schnabl (2012), Chodorow-Reich (2014), Jimenez, Mian, Peydro, and Saurina Salas (2014), Iyer, Peydro, da Rocha-Lopes, and Schoar (2014), Acharya, Eisert, Eufinger, and Hirsch (2014), Cingano, Manaresi, and Sette (2016), Bottero, Lenzu, and Mezzanotti (2016), De Jonghe, Dewachter, Mulier, Ongena, and Schepens (2016) and Heider, Saidi, and Schepens (2017). ${ }^{11}$

\footnotetext{
${ }^{9}$ As measured by the liquid asset ratio, where liquid assets include cash holdings, U.S. Treasuries, U.S. government agency debt, and agency-backed MBS.

${ }^{10}$ Focusing primarily on insurance companies (though also including more restricted analysis of banks), Kirti (2017) finds similar tendencies of institutions hit hardest in the recent crisis to reduce their risk profile, noting the contrast with traditional theories of 'gambling for resurrection'.

${ }^{11}$ This powerful technique relies on the (demanding) requirement that one has access to a credit-register type dataset. Before KM, early tests typically used data at relatively high levels of aggregation - economywide or at the bank level (Bernanke and Lown (1991), Kashyap, Stein, and Wilcox (1993), Hancock and Wilcox (1993), Peek and Rosengren (1995), Stein and Kashyap (2000), Ashcraft (2005), Ashcraft (2006), Calem, Covas, and $\mathrm{Wu}(2013))$. However, as noted by Khwaja and Mian (2008), such studies suffer from
} 


\section{Data}

We use data from the quarterly FR Y-14Q and monthly FR Y-14M filings required of bank holding companies (BHCs) with more than $\$ 50$ billion in assets. The Y14 has been filed since 2012 and contains detailed data on the banks' balance sheet exposures, capital components and categories of pre-provision net revenue. The primary purpose of the filing is to help assess the capital adequacy of banks, in support of supervisory stress testing programs that the Federal Reserve is required to run under the Dodd-Frank Act. Our samples of commercial (residential) loans consist of loans originated by 28 (26) banks and in table 2 we illustrate their characteristics prior to the decline in oil prices. These variables will be used as bank controls in our commercial and residential loan analysis below.

The commercial loan data are from the quarterly corporate loan schedule in the FR Y14Q. This schedule provides a 'credit register' - loan-level information identifying borrower and lender and many characteristics of the loans themselves. Since this paper is one of the first to employ the Y14 data, we provide some perspective on how much of the market for corporate lending we are able to capture. ${ }^{12}$ Table 1 shows that in 2014:Q2, just prior to oil prices' decline, the commercial loans included in the Y14 totaled $\$ 1.17$ trillion, or nearly 70 percent of the $\$ 1.69$ trillion in commercial and industrial loans extended by the entire BHC population that files a FR Y-9C (Y9) report. For perspective, the total amount of debt owed by U.S. nonfinancial corporations at that time was $\$ 2.39$ trillion. Compared to other bank loan data sets used in the literature (e.g., syndicated loans data from the Shared National Credits Program (SNC) or DealScan), the Y14 also captures loans that are typically smaller in size (down to $\$ 1 \mathrm{~m}$ ) and to smaller-scale borrowers. The FR Y-14M filings contain loan-level monthly data on banks' mortgage positions, including characteristics (but not the identity) of the borrower and the mortgage, including their geographical location to a fine level of detail.

the difficulty of separating credit demand and supply effects of shocks to firms and banks. Ideally, one would wish to examine the effect of an isolated shock to bank balance sheets but these shocks often will simultaneously influence firms' demand for credit, making identification difficult. Even if one can identify an exogenous shock that might plausibly be thought only to affect credit supply (see, for example, Peek and Rosengren (1997), Paravisini (2008), Ivashina and Scharfstein (2010), Chava and Purnanandam (2011), Greenstone, Mas, and Nguyen (2014)), there remains the concern that correlated credit demand and supply shifts might confound estimates of the lending channel.

${ }^{12}$ Other papers that have used these novel regulatory data are Abdymomunov (2014) (operational losses), Black, Krainer, and Nichols (2016), Johnson and Sarama (2015), Epouhe and Hall (2016), Calem and Sarama (2016) (real estate) and, making limited use of the corporate loans data to assess the use of private information by syndicate leaders, Balasubramanyan, Berger, Bouwman, and Koepke (2016). For contemporaneous work making use of only the corporate loan data available in the Y14 see Berrospide and Edge (2016) and Luck and Zimmermann (2018). While they do not employ any other Y14 data, Luck and Zimmermann (2018)

do nevertheless explore mortgage lending making use of Home Mortgage Disclosure Act (HMDA) data (the aim being to explore the effects of quantitative easing on banks according to their MBS holdings). 
From the perspective of our work, there are several especially important aspects to the data. First, we are able to look across multiple asset classes. Within the corporate loan sample we are able to distinguish credit lines and term lending, and within mortgages we are able to distinguish those that are securitizable (government loans or conforming to Fannie and Freddie's requirements). Second, for mortgages we know whether the loan is actually held on the balance sheet (a 'portfolio loan') or whether it has been sold off (typically to a GSE) yet remains in our dataset because the bank continues to service the loan. As we will show, if one looks simply at on-balance sheet data, such as in the commonly used Y9 reports, one can be led to believe there is a relative decline in mortgage lending, when in fact there has been an offsetting increase in mortgage origination for securitization. Third, our detailed knowledge of borrowers allows us to construct a measure of bank exposure to oil and gas drillers, which will be the treatment in our study. In addition, since we can track the same borrower across multiple banks, we can exploit within borrower variation that is orthogonal to possibly confounding credit demand effects. ${ }^{13}$ Knowing the borrower also allows us to track their substitution of alternative bank lending when switching banks. Finally, the corporate loan data is not restricted simply to syndicated lending (such as the $\mathrm{SNC}$ and Dealscan, typically used in the literature) and extends down to loan values of $\$ 1 m .{ }^{14}$

In addition to regulatory filings, we use the Federal Reserve's Senior Loan Officer Opinion Survey (SLOOS) to provide insight on banks' lending standards. The SLOOS is a quarterly survey where banks report how various terms and conditions have changed since the previous survey. Importantly, rather than employ the economy-wide aggregate SLOOS responses, we make use of the confidential bank-specific survey responses. ${ }^{15}$ We also use the Federal Deposit Insurance Corporation (FDIC) Summary of Deposits data in constructing an instrument for our exposure variable based on branch location, to be discussed further below.

\section{The oil price decline of 2014}

Figure 1, shows that the oil price fell suddenly and significantly in the middle of 2014 Furthermore, oil futures prices clearly indicate that although a moderate pullback in prices might have been expected, the speed and extent of the decline was a surprise. Indeed, much commentary in the early part of 2014 was bullish on oil (see Hamilton (2014), for

\footnotetext{
${ }^{13}$ For mortgages we use county - rather than borrower specific - fixed effects, as discussed below.

${ }^{14}$ Our dataset is not a superset of syndicated lending data, although the Y14 does provide information that allows one to identify if loans are syndicated. A small fraction of loans in the Dealscan database used by Murfin (2012) and Chodorow-Reich (2014) are for bilateral facilities although the coverage is limited due to the lack of incentive for banks to report such facilities, which are typically arranged privately.

${ }^{15}$ The SLOOS may not be used for supervisory purposes, and the confidential bank-level survey responses may only be used by Federal Reserve System staff in non-supervisory functions for limited-scope economic research projects.
} 
example). We note that our analysis does not require that the oil price be exogenous in the broadest sense. Of course, it is possible (though perhaps not likely in this case) that there are feedbacks from the state of the U.S. banking system to the broader economy and (indirectly) to the oil price. ${ }^{16}$ But that does not undermine our analysis since we exploit variation across the banks in our sample, within the U.S. banking system.

Performance of loans to firms in the O\&G industry depend critically on the market value of oil. As shown in panel A of figure 1, the rate of loans identified as either past due, charged-off, or in non-accrual status (what we refer to as 'problem loans') spiked in the $\mathrm{O} \& \mathrm{G}$ industry following the oil price decline. We define firms as being in the O\&G industry if the bank reported NAICS codes 211, 213111, and 213112 (oil and gas extraction, drilling oil and gas wells, and support activities for oil and gas operations). ${ }^{17}$ Figure 2 shows that these NAICS codes are obvious outliers in terms of being 'net makers' of oil-related products, based on the 'make' and 'use' tables provided by the Bureau of Economic Analysis (BEA). ${ }^{18}$ The fraction of O\&G loans that were in problem status climbed from 0.6 percent in 2014:Q2 to 10.4 percent in 2016:Q3. By contrast, taking all sectors other than O\&G we observe essentially no trend. Restricting the sample to net users of O\&G products (defined as firms in industries with net trade shares less than -0.1 percent - depicted on the left hand side in figure 2) we again observe no obvious pattern. Thus, there was apparently little scope for passive hedging of the shock within the loan book. Loans are debt contracts and given the already low rates of default expected on the typical loan, the upside from having lent to industries whose costs may have declined with the oil price do not offset the downside from exposure to O\&G.

In panel $\mathrm{B}$ of figure 1 we investigate whether difficulties in the $O \& G$ sector led to a liquidity drain for banks - a topic of recent interest given the important role played by losses in liquidity arising from backup facilities and lines of credit in the last crisis (see Cornett, McNutt, Strahan, and Tehranian (2011)). We plot the average utilization rate of credit lines among the same set of sectors as in panel A. While there does appear to be some increase in the utilization rate of credit lines in $O \& G$, relative to the other sectors, the difference does not seem to be particularly dramatic until perhaps the final periods. At the least, the

\footnotetext{
${ }^{16}$ Slowing growth in China and other large emerging economies, increased oil production (from shale and oil sands) in the US and Canada and toleration of lower prices by Saudi Arabia are commonly-cited reasons for the oil price decline. The state of the US economy and bank health do not typically feature as explanations.

${ }^{17}$ Some banks report SIC or GICS codes, but the vast majority report NAICS codes. We map the SIC and GICS to the NAICS industries. See the online data appendix for more details.

${ }^{18} \mathrm{BEA}$ produces year 2007 use and make table for 369 industries, defined by three, four, and five digit NAICS codes. They do not include a separate category for NAICS code 213112. For each industry, we constructed the net trade with industries 324 (petroleum refineries), 211 (oil and gas extraction), 213111 (oil and gas drilling) as a share of that industry's total output. Specifically, the net trade share for industry $i$ is equal to $\frac{M A K E_{324,211,231111}^{i}-U S E_{324,211,231111}^{i}}{O U T P U T^{i}}$.
} 
alignment of the timing of any deterioration with the oil price decline seems much less clear than in the case of loan performance.

Another concern might be the explicit hedging of borrowers' credit risk using derivatives (such as CDS). However, Minton, Stulz, and Williamson (2009) suggest that derivatives positions were largely held by banks for their dealer activities, rather than to protect against the credit risk of their loan book. In addition, we consulted the FR-Y9C and calculated that all but one of our banks had purchased CDS protection of notional value of around 1 percent or lower of their total loan book and the number was approximately 3 percent for the remaining bank. Thus, hedging of credit exposures via derivatives appears to be limited, as theories of adverse and selection and moral hazard might lead us to expect in contexts in which banks have superior information on the underlying loans relative to the broader market (see Duffee and Zhou (2001) for discussions of banks' informational advantage). In addition, recent work by Caglio, Darst, and Parolin (2017) using Y14 and DTCC data, suggests that if anything, banks appear to be net sellers of protection on a substantial fraction of their credit portfolio.

Based on these observations, our analysis will use the banks' loan book exposures to O\&G as our treatment variable. Variation in this exposure implies that some banks experienced larger shocks to their loan books than others when oil prices fell. We calculate O\&G exposure as the share of each bank's total committed exposure (including term loans as well as both drawn and undrawn lines of credit) reported on the Y14 that is accounted for by lending to firms from the O\&G industry over the period 2012:Q3-2013:Q4. We start our sample in 2012:Q3, the date at which the banks that experienced the oil shock period are all present in the Y14 data. We leave a buffer before the period of the price decline to guard against picking up simple reversion to the mean and other concerns of endogeneity.

The average O\&G exposure is 5.9 percent and there is considerable variation across banks, implying a standard deviation of 4.9 percent. Roughly speaking, a one standard deviation increase in pre-shock O\&G exposure represents a 50 basis point increase in the overall problem-loan rate for the 'average' bank over the course of the post period. ${ }^{19}$

It is clear, at least from the market's perspective, that O\&G exposure was important. In figure 3, we group banks into quartile bins based on their pre-shock O\&G exposure. Banks that were more exposed to the O\&G industry, defined here as those in the top quartile, underperformed in terms of their stock prices and market capitalization following the oil price decline. The timing of the separation in performance is notable and is indicative of the repeated guidance given to investors at the time. Further confirmation of the importance of the impact of the oil price decline on bank condition comes from media and survey

\footnotetext{
${ }^{19}$ The fraction of O\&G loans in problem status increased by 9.8 percent points between 2014:Q2 and 2016:Q3. A one standard deviation increase in exposure $(0.049)$ would cause a $0.049 * 9.8=0.5$ percentage point increase in the overall rate.
} 
evidence. The price declines of 2014 drew comment in many quarters and the implications for banks' performance were broadly discussed (Alloway (2014), Jenkins (2014), Noonan and McLannahan (2014)). In fact, in bank surveys the importance of the effects was also emphasized: From the SNC 2016Q1 review - 'The high level of credit risk stems from a large share of risky leveraged finance loans underwritten based on weak practices, and the significant decline in oil prices since mid-2014 that has reduced the repayment capacity of obligors in the oil and gas (OBGG) sector'. Also, from the January 2015 SLOOS 'Some survey respondents specifically noted their concerns about the oil and gas sector resulting from the sharp decline in the price of oil as a reason that they had tightened their lending policies.'

It is important to point out that the committed exposures reported by the banks include both on and off balance sheet amounts. In particular, undrawn or partially drawn credit lines are reflected in the Y14 as loans with utilized exposures lower than the committed exposure. The off-balance-sheet commitments can sum to particularly large amounts. Indeed, committed O\&G loans make up a non-trivial fraction of both total on-balance-sheet loans and total assets, averaging 4.6 and 2.3 percent over the pre-period, respectively. In addition, if one alternatively expresses exposure as a fraction of equity capital, the mean and standard deviation across banks are 19.1 and 21.0 percent, respectively, emphasizing that multiple banks had significant net worth riding on the performance of the O\&G sector and, by implication, oil prices. ${ }^{20}$

\section{De-leveraging or de-risking?}

We begin our results with a high-level analysis based on publicly available bank-level data on important components of the balance sheet - corporate and residential lending and agency MBS holdings. While the insights from these series are suggestive we will then probe deeper, making use of the more granular data from the Y14, augmented with the responses from the SLOOS.

\subsection{Descriptive analysis: FR-Y9C data}

In figure 4 we show how different components of bank balance sheets behaved around the oil price shock, using information from the FR-Y9C. This aggregate bank-level analysis is meant to highlight the direction and timing of the impact, but does not control for timevarying bank-specific covariates or demand factors. For each bank, we regress the logarithm of the bank-level variable on a linear time trend over the pre-2014:Q2 sample. We then

\footnotetext{
${ }^{20}$ While our exposure variable is committed O\&G lending as a share of total committed commercial loans, we also show in a robustness section that our results are robust to using committed O\&G/total on-balancesheet loans and committed $\mathrm{O} \& \mathrm{G} /$ total assets. We also repeat our main regression analyses below using loan exposure as a fraction of equity and find similar results.
} 
collect the residuals and normalize them by taking the log difference relative to the 2014:Q2 value. The unweighted average for banks in the upper (lower) quartile of exposure are given by the red (blue) dashed line.

Panels A and B show that the more exposed banks exhibited lower commercial and residential lending following the shock, in terms of total on-balance sheet loan exposures in these businesses. The timing, again, suggests a noticeable break around the period of the oil shock. While we make no attempt to control for demand factors here, these patterns are consistent with the existence of a bank lending channel to the extent that the reductions in lending reflect a tightening of credit supply. Panel $\mathrm{C}$ shows the analogous plot for agency mortgage backed securities (MBS) and is essentially a mirror image of panel B.

We will delve into the connections between the banks' lending responses and the propensity to securitize, but for now we note that the Y9 data relates to on-balance-sheet exposures such that any mortgages that are securitized will not show up in the balances used to calculate the series in panel B. Instead, they would manifest in MBS holdings. The patterns in these diagrams are therefore suggestive of a more complex set of responses than are normally attributed to the bank lending channel. Finally, we also note that movements out of corporate lending and (to a lesser extent) residential lending, towards MBS signifies a substantial portfolio shift from high risk weighted assets to low - a form of de-risking.

\subsection{Econometric specifications}

The results of the previous section are only suggestive of a tightening of bank credit. In particular, they could entangle credit supply and credit demand effects and omit possibly influential controls. We account for such potential bias in the more granular analysis that follows.

\subsubsection{Regression analysis}

We employ a fixed effects regression of the following form (Khwaja and Mian (2008)):

$$
\Delta Y_{i j}=\beta_{j}+\beta_{1} Z_{i}+\beta_{2} X_{i}+\varepsilon_{i j}
$$

where $Y_{i j}$ is a loan amount between bank $i$ and borrower $j$ from the pre- to the post-shock period. $\beta_{j}$ is a borrower fixed effect, $Z_{i}$ is the bank's exposure to oil (the share of its loans accounted for by O\&G firms in the pre-shock period), and $X_{i}$ are bank controls. We abstract from interactions of $Z_{i}$ with borrower characteristics although they will be used below.

As in Khwaja and Mian (2008) we define a particular loan concept for our empirical analysis. Our concept of a loan is a bank-borrower pair based on the underlying raw loan facility data so that, in examining the intensive margin, $\Delta Y_{i j}$ is the change in the mean

individual loan committed balance within the pair. The mean is a simple average across quarters in the relevant subperiods and we require that there be a continuous bank-firm 
relationship starting before or during the pre-shock period and extending into the postshock period. We focus on term loans as opposed to lines of credit to avoid complexities related to the decision of whether or when to draw upon the line. With term loans we have a clear picture of what funds were being loaned and when these funds were made available. However, the behavior and presence of existing lines of credit will play an important role in our analysis below, so that we do not abandon their information content completely.

For the extensive margin we track the existence of the bank-firm pair in the pre- and post-shock periods, allowing us to apply a linear probability model where $\Delta Y_{i j}$ is replaced by an indicator capturing an exit (a relationship that had been present in the pre-shock period but was not present or came to an end in the post-shock period). ${ }^{21}$

The importance of the fixed effect in equation (1) is that it absorbs the component of the $\Delta Y_{i j}$ that is common across $i$. In particular, it is intended to capture any general shift in the firm's credit demand, common across banks. This addresses concerns that the effects of the oil price shock might induce correlated credit demand and supply shocks, which would lead to endogeneity bias in the regression and confound our measurement of the credit supply effect, captured in $\beta_{1}$. This is the main coefficient of interest as it captures the identified effect on the lending relationship of the credit supply shock arising from the bank's relative exposure. $^{22}$

The interpretation of $\beta_{1}$ is somewhat subtle. Consider, for example, the intensive margin regressions. The coefficient will indicate the association between a bank's oil exposure and the typical change in the amount borrowed from that bank by the firm in question - the response of lending to the identified credit supply shock. However, one should not interpret the coefficient as indicating the amount by which a bank reduces its desired lending, ceteris paribus. Terms of credit are multidimensional so that even if a bank is in some sense still willing to lend the same dollar quantity, it may nevertheless tighten credit along some other margin, such as price or covenants. This could (and we argue below, did) induce a response from firms, such as seeking alternative financing, that would be encoded in any reduction in lending captured by $\beta_{1}$.

\footnotetext{
${ }^{21}$ We discard loans that were 90 or more days past due and restrict our sample only to U.S. borrowers. For all econometric specifications, we remove all loans to firms in the oil and gas industry. Further details of how we cleaned the data are in the online data appendix.

${ }^{22}$ In what follows, we will adopt the standard terminology in this literature (which focuses on separating demand from supply effects) and refer primarily to the fixed effect as absorbing firm-specific shifts in credit demand. Our identification allows us to examine the effects of the oil shock, controlling for credit demand effects, systemic supply effects or effects on lending to particular firms that are common across banks. Thus $\beta_{1}$ relates to the marginal effect arising from banks' relative exposure.
} 


\subsubsection{Identification}

The inclusion of firm fixed effects controls for any factors due to general shifts in a borrower's demand. ${ }^{23}$ However, endogeneity bias could still arise from other supply-side factors. The ideal treatment would entail randomly assigning O\&G exposure across banks. Since our banks chose their exposure to the O\&G sector, it is important to address potential endogeneity.

First, note that we observe an extensive amount of information about the banks in our sample from the FR Y-9 data as shown in Table 2. This includes broad characteristics of the bank (total assets, recent trend in lending, and whether the bank is foreign or domestic), but also characteristics of the banks' risk taking (return on assets, the non-performing loan rate and the charge-off rate) and capital positions (leverage ratio and tier-1 capital ratio). ${ }^{24}$ We also observe the banks' balance sheet structure (loan share of assets, share of residential and commmercial loans in the loan book, and the deposit ratio) which accounts for the banks' preferences for certain asset classes. ${ }^{25}$ Given these observable bank characteristics, the remaining identification assumption in our empirical analysis is that a bank's O\&G exposure is not correlated with any unobserved factors influencing how it responds to a shock. That is, we are concerned about factors, unobserved to the econometrician, that may be correlated with both the bank's decision to hold O\&G loans and its decision to change its balance sheet in response to the shock.

We address this potential endogeneity issue in two ways. First, we examine whether O\&G exposure is correlated with any observable characteristics. If exposure is correlated with any observable bank characteristics then it is plausibly more likely to be correlated with unobserved characteristics. Regressing O\&G exposure on each of the bank variables discussed above indicates no statistically significant relationship with any of these observable variables. This gives some credence to the idea that $O \& G$ exposure is also not correlated with any unobservable factors.

Second, we implement an instrumental variable specification using the banks' 2009 share of branch locations in 'O\&G counties' as an instrument for O\&G exposure (see Gilje, Loutskina, and Strahan (2016) for a similar approach). Specifically, the instrument is the share of bank branches in 2009 that were in counties reporting any income from the O\&G sector. ${ }^{26}$

\footnotetext{
${ }^{23}$ Note that this addresses concerns that the industry and geography of borrowers (absorbed by the fixed effect) could confound our analysis. In particular, the location of borrowers in O\&G intensive areas is accounted for.

${ }^{24}$ The qualitative results do not change when dropping foreign banks, however, dropping the variable reduces the size and the precision of the estimates, somewhat.

${ }^{25}$ Table C.15 in the appendix shows the effects of these control variables on our main estimates.

${ }^{26}$ These are counties where the fraction of non-farm employee compensation attributable to the O\&G industry by county, from 2013 BEA Table CA6N (compensation of employees by industry), was greater than zero. Results were robust to more stringent definitions (e.g. share $>5 \%$ or $>10 \%$ ). The branch data is from the FDIC's Summary of Deposits. All of the Y14 banks in our sample have grown through
} 
This instrument will be strong insofar as certain banks were well placed geographically to originate loans to O\&G and valid to the extent that the location of branches in 2009 is independent to how a bank would respond to a net worth shock in 2014. The exclusion restriction relies on the assumption that branch location is an independent historical decision which subsequently caused its corporate loan book to be more concentrated in certain industries. We cannot fully rule out that banks choose branch location for the sole reason of obtaining corporate loan exposure in certain industries, in which case the instrument is no more valid than O\&G exposure. However, this seems unlikely given that business loans are just one of a multitude of banking services offered at local branches (for example, automatic tellers, consumer loans, and savings accounts). Moreover, it seems even less likely that banks would choose branch location to gain mortgage exposure to households employed in certain industries. Yet we find that using branch structure in an instrumental variables regression yields roughly the same conclusions for both corporate loans and mortgages that are retained in the bank portfolios.

\subsection{Corporate lending}

The first element of the balance sheet we examine is the corporate loan book. In this component, at least, we find the basic message from the aggregate level Y9 data to be broadly confirmed using the greater detail of the Y14.

\subsubsection{Main results}

In table 4 we show regression results on the intensive margin. The coefficient of interest, $\beta_{1}$ (in the first row), is estimated to be negative and significant at the 1 percent level for both the fixed-effects instrumental variables (FE-IV, column 1) and FE regression (column 2). ${ }^{27}$ The point estimates under IV and FE are quite similar, indicating that unobservable supply factors are likely not affecting the FE estimates. The IV-FE and FE coefficients imply that a one standard deviation increase in O\&G exposure (5 percent from table 2 ) is associated with about a 4 percent decline on the intensive margin of a randomly selected loan. ${ }^{28}$

Columns 3 and 4 of table 4 show OLS results under two samples: multi-bank firms (i.e. the FE sample) and the entire Y-14 sample, which includes single-bank firms. By comparing the OLS and FE estimators on the same sample we can assess the size of any bias induced by firm credit demand. If anything, the correlation appears negative: firms that experience

mergers or acquisitions over the past several decades. We choose 2009 to sample the branch data because that is the most distant year in which our banks were all in the Summary of Deposits data in their current organizational forms.

${ }^{27}$ The first-stage estimate shows a strong correlation between O\&G exposure and and 2008 branch share, with a t-statistic of 14 .

${ }^{28}$ Similar results are obtained when we weight observations by the size of loan, indicating that our results are not being driven by the size of the loan. 
positive demand shocks appear more concentrated among banks that experienced negative supply shocks. Thus, endogeneity bias from correlated demand, if there is any, may be towards attenuating the measured effect. In this case, and assuming any correlation between credit supply and demand effects is similar in the larger sample, we may expand our sample and treat the estimated OLS coefficients with reasonable confidence as a lower bound (in magnitude) on the credit supply effect. In the larger sample, we again obtain a statistically significant coefficient on O\&G exposure, although smaller in magnitude than the FE sample $(-0.32)$.

Table 5 shows results on the extensive margin. Similar to the results on the intensive margin, the point estimates of the FE-IV and FE results are similar. A 1 percent increase in $\mathrm{O} \& \mathrm{G}$ exposure is associated with about a 1 percent increase in the probability of exit (columns 1 and 2) with a similar coefficient using OLS (column 2). When (fourth column) we expand the sample to include single bank firms the effect is lower in magnitude and insignificant.

\subsubsection{Exploring the mechanism - corporate lending}

The decline in the magnitude of the estimates when including single-bank firms in the sample suggests that alternative financing opportunities may influence the results. To explore this, we run a specification with three interactions: a dummy that flags whether or not the firm has access to external finance (has a CUSIP or a stock ticker), the pre-period utilization rate that captures the ability of the firm to draw on existing lines of credit, and the number of pre-existing bank relationships (in the Y14 sample), reflecting the costs of switching from an established banking relationship.

Table 6 shows that most of these interactions are statistically insignificant. ${ }^{29}$ However, consistent with the decline in magnitude of the estimate for single-bank firms, there is a statistically significant positive coefficient on the number of pre-existing banking relationships in the exit regression. This suggests that firms with existing alternative banking relationships in the pre-period were more apt to leave their relationship with exposed banks. Since we know the identity of the firms, we can examine if the exiting firm formed a new relationship with another, perhaps less exposed, bank in the Y14 sample. To do so, we run the fixed-effects entry regressions of the type we ran in section 5.3 above, but on different subsamples of firms. In table 8 , we group the firms according to whether they experienced any relationship exit (column 1), did not experience any exit (column 2), experienced any decline in term-loan borrowing from a BHC (column 3), or did not experience any decline in borrowing from a BHC (column 4). Columns 1 and 3 demonstrate that firms that experienced any reduction in lending (by any bank, for any reason) were more likely to strike up

\footnotetext{
${ }^{29}$ We tried introducing these interactions one-by-one. However, they give the same qualitative results as pooling all of the interactions, with more precision on the pre-period utilization rate on the extensive specification.
} 
new relationships with less-exposed banks.

Next, we dig deeper by assessing whether the default risk of the firm also played a role in the probability of exit due to O\&G exposure. Figure 5 shows the implied coefficients of exit on O\&G exposure by default risk. Specifically, we divide all firms in the Y-14 sample into quartiles based on their probability of default (PD), based on the internal credit rating and, where available, PDs provided by banks in the Y14. We run this specification on two samples: the sample of multi-bank firms and single-bank firms. ${ }^{30}$ As in the previous results, the figures show that the probability of exit due to exposure was larger for multibank firms. However, additionally it shows that this exit effect within multi-bank firms was mainly stemming from the lower-risk firms. This result is likely due to the fact that low-risk firms have an easier time finding alternative financing than high-risk firms. In contrast to the evidence at the broader balance sheet level (showing that more exposed banks de-risked), this figure shows no evidence that the more exposed banks de-risked at the corporate loan book level. If anything, more exposed banks were increasing their corporate loan risk due to safer loans leaving the loan book.

These results imply that firms with low-switching costs (i.e., low-risk firms with multiple banking partners) switched from more exposed to less exposed banks. The question than arises: what was causing these firms to flee? A plausible hypothesis is that exposed banks varied their terms of lending, inducing those firms to switch. To examine this hypothesis, we look at the Senior Loan Officer Opinion Survey (SLOOS). The SLOOS is qualitative: respondents indicate whether lending standards have tightened or eased ('somewhat' or 'considerably'), or remained about the same. Importantly, the survey questions ask about lending standards for new loan applications, and thus can be interpreted as the willingness of the banks to supply credit. In figure 6 we plot an index of tightening on loan rates and covenant requirements for commercial and industrial (C\&I) loans. ${ }^{31}$ We again average individual responses of banks in the top and bottom quartiles of exposure. The index shows average cumulative tightening, so a decreasing index depicts banks that have eased terms since the last survey, an increasing index depicts tightening since the last survey.

The banking sector as a whole was generally easing lending standards over this period of time. However, on average, those with relatively high exposure to the oil sector (red lines in figure 6) stopped easing in late 2014 and began to tighten the terms of required loan rates

\footnotetext{
${ }^{30}$ Specifically, we interact O\&G exposure with three dummies, indicating the 2nd through 4th (PD) quartile, the omitted category being the 1st quartile: Exit $t_{i j}=\beta_{j}+\beta_{1,1} Z_{i}+\beta_{1,2} Z_{i} * \mathbf{1}\left(\overline{P D}^{25 t h}<P D_{j}<\right.$ $\overline{P D}^{50 t h}+\beta_{1,3} Z_{i} * \mathbf{1}\left(\overline{P D}^{50 t h}<P D_{j}<\overline{P D}^{75 t h}\right)+\beta_{1,4} Z_{i} * \mathbf{1}\left(\overline{P D}^{75 t h}<P D_{j}\right)+\beta_{2} X_{i}+\varepsilon_{i j}$. We then use the delta method to construct standard errors for the implied effects on the 2 nd $\left(\beta_{1,1}+\beta_{1,2}\right)$, 3rd $\left(\beta_{1,1}+\beta_{1,3}\right)$ and 4 th $\left(\beta_{1,1}+\beta_{1,4}\right)$ quartile firms.

${ }^{31}$ The BHCs in the indexes are ones where we could merge the bank ID in the Y14 data to the SLOOS data. Almost every Y14 bank was also located in the SLOOS.
} 
and loan covenants. ${ }^{32}$ The results from the SLOOS suggest that exposed banks shifted their credit supply function in price relative to less exposed banks.

\subsection{Residential loan analysis}

Our results using the corporate loan book give us interesting insights into how banks respond to shocks and are broadly consistent with the consensus in the literature on the bank lending channel: damage to banks leads to a tightening of credit. A significant advantage of having access to other components of banks' balance sheets is that we can also examine other types of lending. As noted in section 5.1, panel B of figure 4 indicates that residential lending among more exposed banks lagged behind that of the less exposed. In this section, we tease out the underlying drivers of this relationship, showing that this latter conclusion is in some ways misleading.

\subsubsection{Mortgage regression results}

In the case of mortgage lending, we can no longer apply the borrower fixed effects approach at the borrower-bank level because we cannot identify a given household across different banks. However, this fine a level of granularity is likely unnecessary to avoid the aforementioned concerns with confounding credit demand and supply shocks for household borrowing. Since our mortgage data include borrower location data (zip codes) we aggregate to the county-bank level before applying the fixed effects approach to absorb county-level mortgage demand effects.

In table 9 we show the results of our regression analyses. We partition residential loans into those originated and retained on the banks' portfolios ('portfolio loans') and those originated but either sold or securitized with only servicing rights retained ('non-portfolio loans'). We use only those loans originated by the BHCs themselves, excluding those obtained from correspondent relationships. ${ }^{33}$ The different categories of loans are meant roughly to mimic the broad categories included in SLOOS.

For non-government mortgage originations that were retained in the banks' portfolios, the banks are exposed to the credit risk associated with default. The results generally suggest that banks with greater exposure to the oil shock reduced their balance sheet exposure to such mortgages. For both the fixed effects regression in panel A and OLS regression

\footnotetext{
${ }^{32}$ For recent work on the role of covenants in the mechanisms by which banks tighten lending in the syndicated loans market, see Chodorow-Reich and Falato (2017). The Y14 has very granular information on loan quantities and loan performance, but does not contain information on covenants.

${ }^{33}$ We include summary statistics of the log change in mortgage loans and also describe how we partitioned mortgage loans from the Y14 into different types in the online data appendix. The bank level controls are the same as those in our commercial loan analysis, but we augment them with variables capturing trends in the banks' mortgage lending and MBS holdings (see table 3 for a description of the controls). Results are essentially the same if the correspondent and other loans not originated by the banks themselves are included - available on request.
} 
with county controls in panel $\mathrm{B}$ of table 9 , the estimated coefficient of -2.2 implies that a one standard deviation increase in oil exposure leads to a roughly -11.0 percent decline in portfolio lending. We estimate the balance sheet pullback to be stronger in the non-jumbo category (column 3 ) than in the jumbo category (column 2). ${ }^{34}$

Conversely, we see the opposite effect for the non-portfolio loans that were originated and then securitized by the banks. In this case, banks exposed to the oil shock in the corporate portfolio increased their origination and securitization activity (columns 4 and 5). The effect is particularly pronounced when we limit the mortgages to non-jumbo loans, which are more likely to be guaranteed by the GSEs. The coefficient estimate of 3.0 implies that a one standard deviation change in O\&G exposure on the corporate balance sheet is associated with a nearly 14 percent increase in securitization. Similarly, in column 6 of the table we see a significant positive response of changes in loan growth for FHA and VA (i.e. 'government') mortgages-loans likely to be securitized by Ginnie Mae. The coefficient of 8.4 implies a one standard deviation increase in $\mathrm{O} \& \mathrm{G}$ exposure is associated with a 41 percent increase in these types of loans.

These results are consistent with the patterns observed in figure 4. Recall, in that figure (panel C) we observe a substantial increase in aggregate MBS for banks according to their oil exposure. We find no statistically significant change in overall residential loans (column 7). That is, the decline in portfolio loans (again consistent with 4, panel B) was offset by the increase in non-portfolio loans, implying no discernible change in total residential assets. The ultimate effect was a rotation of their balance sheet away from portfolio loans towards non-portfolio loans and, in turn, agency MBS.

\subsubsection{Exploring the mechanism - residential lending}

Figure 7 shows how the evolution of credit terms depended on banks' exposure after the oil price shock. ${ }^{35}$ In panels $\mathrm{A}$ and $\mathrm{B}$ of figure 7 we show the cumulative tightening of terms for GSE-eligible and Government mortgages. We observe that there was a greater tendency on average to loosen terms among the more exposed banks. In contrast, in panels $\mathrm{C}$ and $\mathrm{D}$ we repeat the analysis for jumbo and non-jumbo, non-GSE lending and observe that the pattern is flipped-on average, the more exposed banks seem to have tightened relative to the less exposed. ${ }^{36}$ The (relative) tightening of terms by the more exposed banks is consistent

\footnotetext{
${ }^{34}$ This is reminiscent of results in Calem, Covas, and $\mathrm{Wu}$ (2013) where jumbo, as a share of total mortgage origination, typically rose after the liquidity shock of 2007, although our broader finding of a pull-back in portfolio mortgage lending is somewhat in tension.

${ }^{35}$ Plots begin in 2015:Q1 because the SLOOS questions on mortgages changed at that date.

${ }^{36}$ The GSE-eligible category of residential mortgages includes loans that meet the underwriting guidelines, including loan limit amounts, of the GSEs-Fannie Mae and Freddie Mac. The government category of residential mortgages includes loans that are insured by the Federal Housing Administration, guaranteed by the Department of Veterans Affairs, or originated under government programs, including the U.S. Department of Agriculture home loan programs. The Qualified Mortgage (QM) non-jumbo, non-GSE-eligible
} 
with a decline in their lending as borrowers are less attracted to their loan products. GSEeligible and government mortgages are largely intended to be securitized and shifted off the banks' balance sheets, loosening of terms for these products is consistent with an increase in their off-balance-sheet portfolio.

\subsection{Portfolio implications}

Traditionally, studies on the bank lending channel give the impression that a shock to banks induces a uniform reduction in credit. However, we have shown that the bank's overall response is more complex. More exposed banks pulled back lending, but this pullback was concentrated among loans against which they would be required to hold regulatory capital at a relatively high rate. ${ }^{37}$ In contrast, securitizable lending that was expanded - with relaxation in terms allowing this expansion, as reflected in the SLOOS. This rebalancing is consistent with the Y9 data in that the MBS and residential lending diagrams were essentially mirror images in figure 4. This offsetting pattern adds an important subtlety that might be missed were one only looking at the residential lending data from the Y9. Banks are constantly solving complex optimization problems in their lending behaviors and there is no reason to expect that a pullback in lending will be uniform across all products.

To get a sense of the degree of de-risking we run a simple exercise. We combine our estimated $\beta_{1}$ coefficients from the fixed-effects C\&I and mortgage regressions with the preshock period loan balances and O\&G exposure by bank. This yields an estimated impact of the oil shock arising from the banks' relative exposure. ${ }^{38}$ We find that for the banks in the upper quartile of exposure there is a predicted change of about - 15 percentage points in the average risk weight among the asset classes considered in our regressions (in comparison with a pre-shock average risk weight of $71 \%$ ), whereas for the lower quartile banks the predicted change is about -8 percentage points. ${ }^{39}$ In terms of loan balances, the equivalent figures

category of residential mortgages includes loans that satisfy the standards for a qualified mortgage and have loan balances that are below the loan limit amounts set by the GSEs but otherwise do not meet the GSE underwriting guidelines. The QM jumbo category of residential mortgages includes loans that satisfy the standards for a qualified mortgage but have loan balances that are above the loan limit amount set by the GSEs.

${ }^{37}$ Depending on the LTV and other factors, the prevailing risk weights under the Basel standardized approach over the sample period ranged from 35 percent to potentially over 100 percent for mortgages and, according to the particular agency, 0 percent or 20 percent, for agency MBS

${ }^{38}$ The predicted dollar change is pre-shock lending $\times$ exposure $\times \beta_{1}$.

${ }^{39}$ Note that these calculations are restricted to the parts of the balance sheet for which we have estimated $\beta_{1}$ coefficients. We apply a common set of risk weights to all banks, even though many of these banks actually employ their own risk weights developed for the advanced internal models approach under Basel 3 capital standards. The assumed risk weights $w_{k}$ for asset class $k$ are as follows. Corporate loans carry a 100\% weight, portfolio mortgages carry a 50\% weight, GSE-eligible nonportfolio mortgages carry a $20 \%$ weight, and government-insured mortgages carry a $0 \%$ weight. With these assumptions, our average risk 
are -3 and +0.1 percentage points, respectively, reflecting the reallocation rather than a wholesale reduction in credit that our estimates imply.

The above exercise assesses the degree of de-risking within a portion of the banks' balance sheet: commercial and residential loans. Of course, one would like to extend this analysis to include all elements of the balance sheet, though this would be beyond the scope of this paper. Nevertheless, we can obtain evidence that the patterns we have uncovered refect a general strategy by the banks. Thus, we regress the logarithm of bank-level variables on time-dummies interacted with O\&G exposure, time dummies interacted with bank controls, time dummies, bank fixed effects, and bank-specific time trends. ${ }^{40}$

In figure 8 we show coefficients and 95-percent confidence bands of the coefficients on the time dummies interacted with O\&G exposure, where the dependent variable is the riskweighed asset ratio (Panel A), the liquid assets ratio (Panel B), the leverage ratio (Panel C), and log total assets (Panel D). Panel A shows that there is a statistically significant movement downwards in the average risk weight across the balance sheet among banks who were more exposed to the oil shock. A one standard deviation increase in exposure amounts to about a 200 basis point decrease in the risk-weighed asset ratio, interpretable as the average risk weight. The pattern is consistent with our more granular regression evidence. In contrast, the relative behavior of total assets and leverage show no obvious or statistically significant pattern. Thus, we find evidence of de-risking, but little evidence of de-leveraging in the traditional sense.

By looking for coordinated actions across the balance sheet, shows that the bank lending channel is a much more subtle concept than is typically allowed. Since the financial crisis there has been much demand for analyses of how banks behave when damaged and for there to be a greater understanding of the detailed interlinkages within their balance sheets and

weight measure for bank $i$ is defined by

$$
\tilde{w}_{i} \equiv \sum_{k} w_{k} L_{i k} / \sum_{k} L_{i k}
$$

where $L_{i k}$ is bank $i$ 's loan exposure in asset category $k$.

${ }^{40}$ Omitted periods in the regression are 2012:Q3 and 2014:Q2, implying bank-specific time trends capture pre-shock trends. Bank controls include pre-shock loan-weighted average levels of ROA, equity/total assets, NPL/total assets, tier-1 capital/risk-weighted assets, total loans/total assets, charge offs/total loans, commercial loans/total loans, residential loans/total loans, deposits/total liabilities, and a foreign bank dummy. O\&G exposure was normalized to have unit standard deviation. The risk-weighted assets ratio is defined as total risk-weighted assets divided by total assets. The liquid asset ratio is defined as liquid assets divided by total assets, where liquid assets are defined as cash holdings, U.S. Treasuries, U.S. government agency debt, and agency-backed MBS. The leverage ratio is defined as total assets divided by equity. All data are from the FR-Y9. Standard errors are clustered by bank. To correct for a coding change in risk weights implemented by Basel III in 2015:Q1, the risk-weighted asset ratio (panel D) for 2015:Q1 for each bank was spliced with its 2014:Q4 value. 
their role as intermediaries - for different sectors and classes of borrowers. Our de-risking results speak to these important debates. ${ }^{41}$

\section{6. (Weak) credit channel}

The ability to substitute alternative funding sources is an important determinant of the ultimate impact of the oil shock on borrowers. Our main focus above has been to tell primarily a 'bank-level' story regarding the banks' de-risking behavior. Our second main contribution comes from analyzing how the banks' decisions ultimately affected borrowers i.e., the 'credit channel'.

To assess the credit channel, we run a specification similar to (1), but aggregated to the level of the borrower:

$$
\Delta Y_{j}=\beta_{0}^{F}+\beta_{1}^{F} \bar{Z}_{j}+\beta_{2}^{F} W_{j}+\beta_{3}^{F} \bar{X}_{j}+\eta_{j}
$$

where $\Delta Y_{j}$ is the change (from pre- to post-oil shock) in an attribute $Y$ of firm $j .{ }^{42} \bar{Z}_{j}^{F}$ is the weighted average O\&G exposure of the banks from whom firm $j$ borrowed in the pre-shock period. The variable is meant to capture how exposed the firm was to the credit supply effects induced by the oil price shock, via the banks with whom it was associated. $W_{j}$ are firm controls and $\bar{X}_{j}$ are weighted averages of the characteristics of the banks. $\beta_{1}^{F}$ indicates whether or not firms were systematically affected by being exposed indirectly to the oil shock. If we find that oil exposure typically induces a tightening of credit supply then one might expect a non-zero coefficient if firms are unable to substitute alternative financing. However, if the firm can substitute for any reduced financing or away from lending on worsened terms, then one might not expect any effect.

In table 7 we show results for various dependent variables. The first two columns of table 7 relate to the change in firms' total term loan borrowing and total borrowing from Y14 banks, respectively. These regressions show a statistically insignificant relationship with the aggregate exposure variable, implying that firms that were borrowing from more exposed banks in the pre-shock period had no net change in their term loans due to the credit supply shock. This result implies that firms were able to substitute simply from other Y14 banks.

In columns 3-5 we move beyond the Y14 borrowing to look at additional balance sheet objects from Compustat. Here we see no statistically significant estimates, implying essentially no relationship between changes in total liabilities (or assets, or equity) and the aggregate exposure variable. Overall, in spite of the significant adjustments that exposed BHCs were

\footnotetext{
${ }^{41}$ Since raising capital requirements are, in some sense comparable to a shock to net worth, our results also relate to discussions on these important policy tools (see Furlong and Keeley (1989), Laeven and Levine (2009) and, more recently, Landvoigt and Begenau (2017)).

${ }^{42}$ Or county $j$ for the mortgage results.
} 
making in the wake of the oil price shock, borrowing firms (at least in the Compustat sample) were apparently able to smooth out the effects of the shift in credit supply using other means. ${ }^{43}$

To pin down a particular channel for substitution, we isolate those firms that switched banks (among the Y14 filers). Returning to table 8 (column 5), we run our firm-level regressions with the dependent variable being a dummy variable equal to one if the firm exited at least one banking relationship and entered at least one banking relationship. The coefficient on aggregate $\mathrm{O} \& \mathrm{G}$ exposure is positive and statistically significant, indicating that those firms more exposed to the credit supply shock were more likely to switch banks. ${ }^{44}$

We also consider the ultimate effect on mortgage borrowing at the county level. Table 10 contains the aggregate regressions, where we relate changes in county-level mortgage balances to the counties' aggregate exposure (analogous to the corporate case). We assess three different categories: portfolio loans, all Y14 loans, and all loans from the Black KnightMcDash Analytics database, which samples loans from the universe of lenders and not just those in the Y14. For all three levels of aggregation there is no statistically significant effect on loan quantity, again suggesting a limited broad credit channel and suggestive of a large degree of substitution to other lenders by households in exposed counties.

There are of course a couple of caveats to our result of a limited credit channel. First, it is possible that firms who were unable or unwilling to switch banks and who chose to maintain their same scale of borrowing may possibly have suffered in other dimensions due to the worse terms they may have faced. Second, responses to a larger shock during a systemic tightening might plausibly differ from our findings, as suggested by Chodorow-Reich (2014) and other crisis era papers. Nevertheless, it is interesting that in our case, which may be thought representative of a 'normal shock in normal times', the degree of substitutability of credit seems substantial. Thus we provide a benchmark for studies focusing on more turbulent times.

\section{Robustness}

While anecdotal reports and the banks' answers in lending surveys give support to our regressions and our overall story, in this section we carry out a set of robustness checks.

\footnotetext{
${ }^{43}$ We use the Compustat variables in this case because they are obtained from official financial statements and should be more accurate than bank-reported equivalents in the Y-14. The sample size declines substantially in columns 3-5 of table 7 due to the requirement that Compustat firms be publicly traded. Jimenez, Mian, Peydro, and Saurina Salas (2014) suggest a bias adjustment (described in the online descriptive appendix) to the firm level estimated coefficient based on comparing the bank-firm level coefficients from FE and OLS regressions. Making this adjustment does not materially change our insights.

${ }^{44}$ We examined whether firms initially borrowing from more exposed banks drew on open lines of credit. While there seemed to be little evidence overall, there appeared to be an effect for firms with relatively large shares of their borrowing capacity untapped (results are available on request).
} 
First, we consider the implications of defining our exposure variable as a share of total onbalance-sheet loans, of total assets, and of equity capital (all as reported in the FR Y-9C) rather than as a share of total committed commercial loan exposure. The motivation for this (though Chodorow-Reich (2014) also scales his exposure by loans, for example) is that the size of the loan book and capital position of banks may differ, implying noise and possibly bias in our index. Table 12 shows that these changes do not substantially alter our findings.

A possible concern is that our regression specification contains too few clusters, leading to either 'overfitting' of the cluster-robust variance matrix estimate or over-rejection of the critical values (Cameron and Miller (2015)). There is no definitive measure of 'too few', but the general consensus is around 30 clusters - close to the number of banks in our sample. To address this issue, we re-assess our standard errors using the wild cluster bootstrap recommended by Cameron and Miller (2015). Table 13 shows the p-values on $\beta_{1}$ for all of our firm-bank and county-bank pair regressions, under the wild cluster bootstrap. We also include in the table p-values under the amended definition of bank exposure, in which we scale committed balances by bank equity, rather than total committed C\&I loan balances. The results coincide with our main results above using two-way clustering, showing strong statistical significance for the C\&I, portfolio residential, and government residential lending, but noisier results on non-portfolio non-government lending. ${ }^{45}$

There is also a potential concern that the predictive power of our exposure variable was somehow a coincidence. To address this possibility we conducted a placebo test. Formally, we run a type of permutation test using each bank's loan exposure to other industries as placebos. That is, we test whether exposure to any other industry delivers similar results to exposure to the $\mathrm{O} \& \mathrm{G}$ sector. Analogous to the $\mathrm{O} \& \mathrm{G}$ exposure variable used throughout this paper, for each of the most prevalent other 49 industries (defined by 3-digit NAICS) we create a bank-specific exposure variable analogous to our O\&G exposure variable. We then run our main fixed-effects specification 50 times - once replicating our original specification, and 49 subsequent regressions using the alternative industry exposures. To be conservative, we collected the associated t-statistic based upon the standard errors obtained from the wild cluster bootstrap. In figure 9 we show the distribution of t-statistics obtained from our intensive and extensive corporate lending regressions. Clearly, sampling variability associated with this test means that, even if our O\&G exposure variable were the 'true' exposure variable, it would not necessarily emerge as having the largest t-statistic. However, we would at least hope for it to be in the tail. In fact, the results are extremely strong. In the intensive regressions, our exposure variable is a clear outlier in the left tail (where the left tail is most relevant given the limited upside to a debt contract) and in the right tail in the

\footnotetext{
${ }^{45}$ Although clustering should guard against an individual bank driving our results we also ran our commercial intensive and extensive fixed effect regressions repeatedly, each time removing a different bank from the sample. We retained significance in all cases and the coefficient value was consistent (average and standard deviation of -0.81 and 0.06 , respectively, for intensive and 0.84 and 0.08 for the exit regressions).
} 
extensive regressions.

Roughly contemporaneous to the oil price shock, U.S. banking regulators were in the process of phasing in new balance sheet liquidity requirements for many of the banks in our sample. The new regulations stipulated that banks maintain a Liquidity Coverage Ratio (LCR) whereby liquid assets could be used to offset possible funding outflows in a period of stress. The rule may have influenced the demand for liquid assets for certain banks, which include agency MBS. In the U.S., BHCs with assets over $\$ 250$ billion needed to meet 80 percent of their liquidity requirements in 2015 (i.e., in our post-shock window). BHCs with assets above $\$ 50$ billion but below $\$ 250$ billion were subject to a modified and less severe LCR requirement with a phase-in period in 2016 (i.e., outside our post-shock window).

In response, we construct an indicator variable to identify banks with assets over $\$ 250$ billion and subject to the LCR phase-in in 2015, and then interact this variable with a proxy for exposure to the LCR in the pre oil-shock period. This proxy consists of a measure of high-quality liquid assets (Treasury Securities + Agency MBS) which is then scaled by a measure of possible funding outflows (Total Liabilities - Deposits). Thus, BHCs with large values for the proxy have ample liquidity, or are more reliant on deposits (or both), and thus would be less constrained by the LCR. When we include these variables among the bank controls in our regressions we find only small quantitative differences in the estimates of the sensitivity of lending to O\&G exposure and no differences in statistical significance. Indeed, the coefficients on the LCR controls are not statistically significant in any of the mortgage regressions.

Finally, although it is less a robustness test than a useful re-expression, we recast our shock in terms of its relative impact on bank valuations. To do so, we run a two-stage specification of our model, first regressing the bank's change in log market capitalization (between the pre and post period) on the bank's O\&G exposure and then using this fitted change in valuation to explain the various changes in loans discussed above. In this way, we obtain an elasticity of lending with respect to a change in market capitalization attributable to the oil price shock. This allows us to map the oil shock into a common scale that might be transferrable to other studies, rather than leaving it in terms of exposure to a particular industry.

In table 11 we repeat our main regressions under this two stage approach. We lose some power through this procedure but qualitatively our results are confirmed and in most cases we retain statistical significance. Our results imply that a 1 percent hit to net worth leads to a 0.90 percent decline in corporate lending on the intensive margin and a 0.95 percent increase in the probability of exit. In terms of mortgage lending, the response is a 1.8 percent decline for non-government portfolio loans, 0.6 percent increase for non-government non-portfolio, and a 3.5 percent increase for government loans. Our aggregate regressions again suggest that the ultimate impact on exposed borrowers was minimal, relative to those borrowing from less exposed banks. 


\section{Conclusions}

Banks damaged by exposure to industries adversely affected by the oil price decline made significant adjustments to their balance sheets. Banks de-risked their balance sheet by undertaking actions that reduced their average risk weight. We document a significant pull-back in commercial lending by exposed banks, both on the intensive and the extensive margins. Importantly, however, the balance sheet adjustments by banks exposed to the oil price shock were not confined to the corporate loan portfolio where the shock might be expected to have its most direct impact. Exposed banks tightened credit supply for those mortgages that they would have to hold in their own portfolios, while expanding credit for loans that were government-backed and could be securitized. Overall, it appears there was a tendency of the damaged banks to de-leverage by de-risking. This is a new insight relative to the traditional 'bank lending channel' view which emphasizes a general de-leveraging and pull back in lending.

Ultimately, the relative impact on borrowers who were particularly exposed to damaged banks appears to have been limited. The ability to substitute to alternative financing sources largely allowed borrowers to smooth through any credit tightening imposed by the exposed banks - although it is still possible that firms unable to switch banks easily may have suffered from worsened credit terms even as they maintained their quantity of borrowing. This likely reflects the health of the U.S. financial system in 2014 and the moderate size of the shock, but nevertheless we provide a benchmark for studies of larger shocks in more turbulent periods. 


\section{References}

Abbassi, P., R. Iyer, J.-L. Peydro, and F. R. Tous (2016): "Securities trading by banks and credit supply: Micro-evidence from the crisis," Journal of Financial Economics, 121(3), 569 594.

Abdymomunov, A. (2014): "Banking Sector Operational Losses and Macroeconomic Environment," Unpublished paper.

Acharya, V. V., T. Eisert, C. Eufinger, And C. Hirsch (2014): "Real Effects of the Sovereign Debt Crisis in Europe: Evidence from Syndicated Loans," CEPR Discussion Papers 10108, C.E.P.R. Discussion Papers.

Acharya, V. V., and S. Viswanathan (2011): "Leverage, Moral Hazard, and Liquidity," The Journal of Finance, 66(1), 99-138.

Alloway, T. (2014): "Oil price fall starts to weigh on banks," FT.com [Online; posted 26November-2014].

Ashcraft, A. B. (2005): "Are Banks Really Special? New Evidence from the FDIC-Induced Failure of Healthy Banks," The American Economic Review, 95(5), 1712-1730.

(2006): "New Evidence on the Lending Channel," Journal of Money, Credit and Banking, $38(3), 751-775$.

Balasubramanyan, L., A. N. Berger, C. H. Boumman, and M. M. Koepke (2016): "How Do Lead Banks Use Their Private Information about Loan Quality in the Syndicated Loan Market?," Working Paper 16-16, Federal Reserve Bank of Cleveland.

Bernanke, B., And C. S. Lown (1991): "The Credit Crunch," Brookings Papers on Economic Activity, 22(2), 205-248.

Bernanke, B. S., And A. Blinder (1992): "The Federal Funds Rate and the Channels of Monetary Transmission," American Economic Review, 82(4), 901-921.

Berrospide, J. M., And R. Edge (2016): "The Effects of Bank Capital Requirements on Bank Lending: What Can We Learn from the Post-crisis Regulatory Reforms," Working draft, Federal Reserve Board.

Black, L., J. Krainer, and J. Nichols (2016): "From Origination to Renegotiation: A Comparison of Portfolio and Securitized Commercial Real Estate Loans," The Journal of Real Estate Finance and Economics, pp. 1-31.

Bottero, M., S. Lenzu, And F. Mezzanotti (2016): "Sovereign Debt Exposure and the Bank Lending Channel: Impact on Credit Supply and the Real Economy," Joint wb-imf seminar, World Bank - IMF. 
Caglio, C., R. M. Darst, and E. Parolin (2017): "Half-full or Half-empty? A Direct Test of the Impact of CDS Trading on Corporate Credit Risk," .

Calem, P., F. Covas, And J. Wu (2013): "The Impact of the 2007 Liquidity Shock on Bank Jumbo Mortgage Lending," Journal of Money, Credit and Banking, 45(s1), 59-91.

Calem, P. S., And R. F. Sarama (2016): "Why Mortgage Borrowers Persevere: An Explanation of First and Second Lien Performance Mismatch," Real Estate Economics.

Cameron, A. C., And D. L. Miller (2015): "A practitioner's guide to cluster-robust inference," Journal of Human Resources, 50(2), 317-372.

Chakraborty, I., I. Goldstein, and A. MacKinlay (2018): "Housing price booms and crowding-out effects in bank lending," The Review of Financial Studies, 31(7), 2806-2853.

— (2019): "Monetary stimulus and bank lending," Journal of Financial Economics.

Chava, S., And A. Purnanandam (2011): "The effect of banking crisis on bank-dependent borrowers," Journal of Financial Economics, 99(1), 116 - 135.

Chodorow-Reich, G. (2014): "The Employment Effects of Credit Market Disruptions: Firmlevel Evidence from the 20089 Financial Crisis," The Quarterly Journal of Economics, 129(1), $1-59$.

Chodorow-Reich, G., And A. Falato (2017): "The Loan Covenant Channel: How Bank Health Transmits to the Real Economy," .

Cingano, F., F. Manaresi, and E. Sette (2016): "Does Credit Crunch Investment Down? New Evidence on the Real Effects of the Bank-Lending Channel," Review of Financial Studies.

Cornett, M. M., J. J. McNutt, P. E. Strahan, and H. Tehranian (2011): "Liquidity risk management and credit supply in the financial crisis," Journal of Financial Economics, 101(2), $297-312$.

De Jonghe, O., H. Dewachter, K. Mulier, S. Ongena, and G. Schepens (2016): "Some Borrowers are More Equal than Others: Bank Funding Shocks and Credit Reallocation," Unpublished paper.

den HaAn, W. J., S. W. Sumner, and G. M. Yamashiro (2007): "Bank loan portfolios and the monetary transmission mechanism," Journal of Monetary Economics, 54(3), $904-924$.

Diamond, D. W. (1989): "Reputation Acquisition in Debt Markets," Journal of Political Economy, 97(4), 828-862.

Drechsler, I., A. Savov, And P. Schnabl (2018): "Banking on Deposits: Maturity Transformation without Interest Rate Risk," Working Paper 24582, National Bureau of Economic Research. 
Du, W., A. Tepper, And A. Verdelhan (2018): "Deviations from Covered Interest Rate Parity," Journal of Finance, forthcoming.

Duffee, G. R., And C. Zhou (2001): "Credit derivatives in banking: Useful tools for managing risk?," Journal of Monetary Economics, 48(1), 25 - 54.

Epouhe, O., AND A. Hall (2016): "Payment shock in \{HELOCs\} at the end of the draw period," Journal of Economics and Business, 84, 131 - 147, Special Issue on Regulating Consumer Credit.

Froot, K. A., And J. C. Stein (1998): "Risk management, capital budgeting, and capital structure policy for financial institutions: An integrated approach," Journal of Financial Economics, $47(1), 55-82$.

Furlong, F. T., And M. C. Keeley (1989): "Capital regulation and bank risk-taking: A note," Journal of Banking $\&$ Finance, 13(6), 883 - 891.

Gilje, E. P., E. Loutskina, and P. E. Strahan (2016): "Exporting Liquidity: Branch Banking and Financial Integration," The Journal of Finance, 71(3), 1159-1184.

Greene, W. (2004): "Fixed effects and bias due to the incidental parameters problem in the Tobit model," Econometric reviews, 23(2), 125-147.

Greenstone, M., A. Mas, And H.-L. Nguyen (2014): "Do Credit Market Shocks affect the Real Economy? Quasi-Experimental Evidence from the Great Recession and Normal Economic Times," Working Paper 20704, National Bureau of Economic Research.

Hamilton, J. D. (2014): "The Changing Face of World Oil Markets," NBER Working Papers 20355, National Bureau of Economic Research, Inc.

Hancock, D., AND J. A. Wilcox (1993): "Has There Been a Capital Crunch in Banking? The Effects on Bank Lending of Real Estate Market Conditions and Bank Capital Shortfalls," Journal of Housing Economics, 3(1), 31 - 50.

Heider, F., F. SAidi, And G. Schepens (2017): "Life Below Zero: Bank Lending Under Negative Policy Rates," .

Holmstrom, B., And J. Tirole (1997): "Financial Intermediation, Loanable Funds, and The Real Sector," The Quarterly Journal of Economics, 112(3), 663-691.

Huber, K. (2018): "Disentangling the Effects of a Banking Crisis: Evidence from German Firms and Counties," American Economic Review, 108(3), 868-98.

Ivashina, V., And D. Scharfstein (2010): "Bank lending during the financial crisis of 2008," Journal of Financial Economics, 97(3), 319 - 338, The 2007-8 financial crisis: Lessons from corporate finance. 
Iyer, R., J.-L. Peydro, S. dA Rocha-Lopes, And A. Schoar (2014): "Interbank Liquidity Crunch and the Firm Credit Crunch: Evidence from the 2007-2009 Crisis," Review of Financial Studies, 27(1), 347-372.

JEnkins, P. (2014): "Falling oil price poses new threat to banks," FT.com [Online; posted 15December-2014].

Jensen, M. C., And W. H. Meckling (1976): "Theory of the firm: Managerial behavior, agency costs and ownership structure," Journal of Financial Economics, 3(4), 305 - 360.

Jimenez, G., A. R. Mian, J.-L. Peydro, and J. Saurina Salas (2014): "The Real Effects of the Bank Lending Channel," Unpublished paper.

Jimenez, G., S. Ongena, J.-L. Peydro, and J. Saurina (2012): "Credit Supply and Monetary Policy: Identifying the Bank Balance-Sheet Channel with Loan Applications," American Economic Review, 102(5), 2301-26.

Johnson, K. W., And R. F. Sarama (2015): "End of the Line: Behavior of HELOC Borrowers Facing Payment Changes," Working Paper 2015-073, Federal Reserve Board.

Kashyap, A. K., And J. C. Stein (1993): "Monetary Policy and Bank Lending," NBER Working Papers 4317, National Bureau of Economic Research, Inc.

Kashyap, A. K., J. C. Stein, And D. W. Wilcox (1993): "Monetary Policy and Credit Conditions: Evidence from the Composition of External Finance," American Economic Review, 83(1), 78-98.

Khwaja, A. I., And A. Mian (2008): "Tracing the Impact of Bank Liquidity Shocks: Evidence from an Emerging Market," American Economic Review, 98(4), 1413-42.

KIRTI, D. (2017): "When Gambling for Resurrection is Too Risky," IMF WP/17/180.

Laeven, L., And R. Levine (2009): "Bank governance, regulation and risk taking," Journal of Financial Economics, 93(2), 259 - 275.

Landier, A., D. Sraer, And D. Thesmar (2013): "Banks Exposure to Interest Rate Risk and The Transmission of Monetary Policy," TSE Working Papers 13-438, Toulouse School of Economics (TSE).

Landvoigt, T., And J. Begenau (2017): "Financial Regulation in a Quantitative Model of the Modern Banking System," Discussion paper.

Liberti, J. M., And J. Sturgess (2018): "The Anatomy of a Credit Supply Shock: Evidence from an Internal Credit Market," Journal of Financial and Quantitative Analysis, 53(2), 547579.

Loutskina, E. (2011): "The role of securitization in bank liquidity and funding management," Journal of Financial Economics, 100(3), 663 - 684. 
Loutskina, E., And P. E. Strahan (2009): "Securitization and the Declining Impact of Bank Finance on Loan Supply: Evidence from Mortgage Originations," The Journal of Finance, 64(2), 861-889.

Luck, S., And T. Zimmermann (2018): "Employment Effects of Unconventional Monetary Policy: Evidence from QE," .

Minton, B. A., R. Stulz, and R. Williamson (2009): "How Much Do Banks Use Credit Derivatives to Hedge Loans?," Journal of Financial Services Research, 35(1), 1-31.

Murfin, J. (2012): "The Supply-Side Determinants of Loan Contract Strictness," The Journal of Finance, 67(5), 1565-1601.

Noonan, L., And B. McLannahan (2014): "US banks hit by cheap oil as Opec warns of longterm low," FT.com [Online; posted 23-December-2015].

Ongena, S., J. L. Peydro, And N. van Horen (2013): "Shocks Abroad, Pain at Home? BankFirm Level Evidence on the International Transmission of Financial Shocks," DNB Working Papers 385, Netherlands Central Bank, Research Department.

Paravisini, D. (2008): "Local Bank Financial Constraints and Firm Access to External Finance," The Journal of Finance, 63(5), 2161-2193.

Peek, J., And E. S. Rosengren (1995): "The Capital Crunch: Neither a Borrower nor a Lender Be," Journal of Money, Credit and Banking, 27(3), 625-638.

- (1997): "The International Transmission of Financial Shocks: The Case of Japan," The American Economic Review, 87(4), 495-505.

Peek, J., And J. A. Wilcox (2003): "Secondary Mortgage Markets, GSEs, and the Changing Cyclicality of Mortgage Flows," Unpublished paper.

Potter, S. (2013): "Recent developments in monetary policy implementation," Remarks at the Money Marketeers of New York University, New York City.

Rampini, A. A., S. Viswanathan, And G. Vuillemey (2017): "Risk Management in Financial Institutions," .

Schnabl, P. (2012): "The International Transmission of Bank Liquidity Shocks: Evidence from an Emerging Market," The Journal of Finance, 67(3), 897-932.

Stein, J. C. (1998): "An Adverse-Selection Model of Bank Asset and Liability Management with Implications for the Transmission of Monetary Policy," The RAND Journal of Economics, 29(3), 466-486.

Stein, J. C., And A. K. Kashyap (2000): "What Do a Million Observations on Banks Say about the Transmission of Monetary Policy?," American Economic Review, 90(3), 407-428. 
Stiglitz, J. E., AND A. Weiss (1981): "Credit Rationing in Markets with Imperfect Information," American Economic Review, 71(3), 393-410.

Tella, S. D., And P. Kurlat (2017): "Why are Banks Exposed to Monetary Policy?," Working Paper 24076, National Bureau of Economic Research.

Wasi, N., And A. FlaAen (2015): "Record linkage using Stata: Preprocessing, linking, and reviewing utilities," Stata Journal, 15(3), 672-697(26). 
Table 1: Assessing the coverage of the Y14

\begin{tabular}{lc}
\hline \hline & \\
& $\$$ Billions \\
\hline Y-14 total utilized balances & 1,170 \\
Total commercial loans from all BHCs & 1,691 \\
Loans to U.S. nonfinancial corporates & 2,386 \\
\hline \hline
\end{tabular}

Sources: Federal Reserve Board of Governors

Table 2: Bank summary statistics - average values pre-oil shock

\begin{tabular}{|c|c|c|c|c|}
\hline & \multicolumn{2}{|c|}{ Commercial Loan Analysis } & \multicolumn{2}{|c|}{ Residential Loan Analysis } \\
\hline & Mean & Std. Dev. & Mean & Std. Dev. \\
\hline Total assets (\$billions) & 474 & 675 & 466 & 694 \\
\hline Non-performing loan ratio (commercial loans) & .010 & .007 & .010 & .007 \\
\hline Tier-1 Capital Ratio & .129 & .020 & .126 & .016 \\
\hline Mean ROA (quarterly) & .002 & .001 & .002 & .001 \\
\hline Equity/Total assets & .116 & .023 & .118 & .022 \\
\hline On-balance-sheet total loans/Total assets & .526 & .225 & .561 & .192 \\
\hline On-balance-sheet commercial loans/Total on-balance-sheet loans & .240 & .104 & .252 & .096 \\
\hline On-balance-sheet residential loans/Total on-balance-sheet loans & .285 & .135 & .306 & .116 \\
\hline Total charge-offs/Total on-balance-sheet loans & .006 & .005 & .006 & .005 \\
\hline Deposit share of total liabilities & .726 & .231 & .748 & .201 \\
\hline Foreign bank dummy & .214 & & .231 & \\
\hline Lag $\Delta \log$ commercial loans (2012:Q3 to 2014:Q2) & .326 & .662 & & \\
\hline Lag $\Delta \log$ residential loans (2012:Q3 to 2014:Q2) & & & -.025 & .201 \\
\hline Lag $\Delta \log$ MBS (2012:Q3 to 2014:Q2) & & & .038 & .700 \\
\hline Committed O\&G loans/Total committed commercial loans & .059 & .049 & .060 & .049 \\
\hline Committed O\&G loans/Total on-balance-sheet loans & .046 & .042 & .045 & .041 \\
\hline Committed O\&G loans/Total assets & .023 & .027 & .025 & .027 \\
\hline Committed O\&G loans/Equity & .194 & .210 & .205 & .213 \\
\hline Observations & 28 & & 26 & \\
\hline
\end{tabular}

Notes: Data are from the Y9-C and are taken as the average from the 2012:Q3 to 2014:Q2 period. Lag $\Delta \log$ commercial loans, lag $\Delta \log$ residential loans, and lag $\Delta \log$ MBS are constructed as the change between 2012:Q3 and 2014:Q2. "Committed O\&G loans" are commercial loan commitments made to firms in NAICS codes 211, 213111, and 213112, taken from the Y14 data. "Committed O\&G loans/Total committed commercial loans," "Committed O\&G loans/Total on-balance-sheet loans," "Committed O\&G loans/Total assets," and "Committed O\&G loans/Equity" are calculated as the quarterly average over the 2012:Q3 to 2013:Q4 period. "Committed O\&G loans/Total committed commercial loans" is the main exposure variable used throughout the paper, referred to as "O\&G Exposure." 


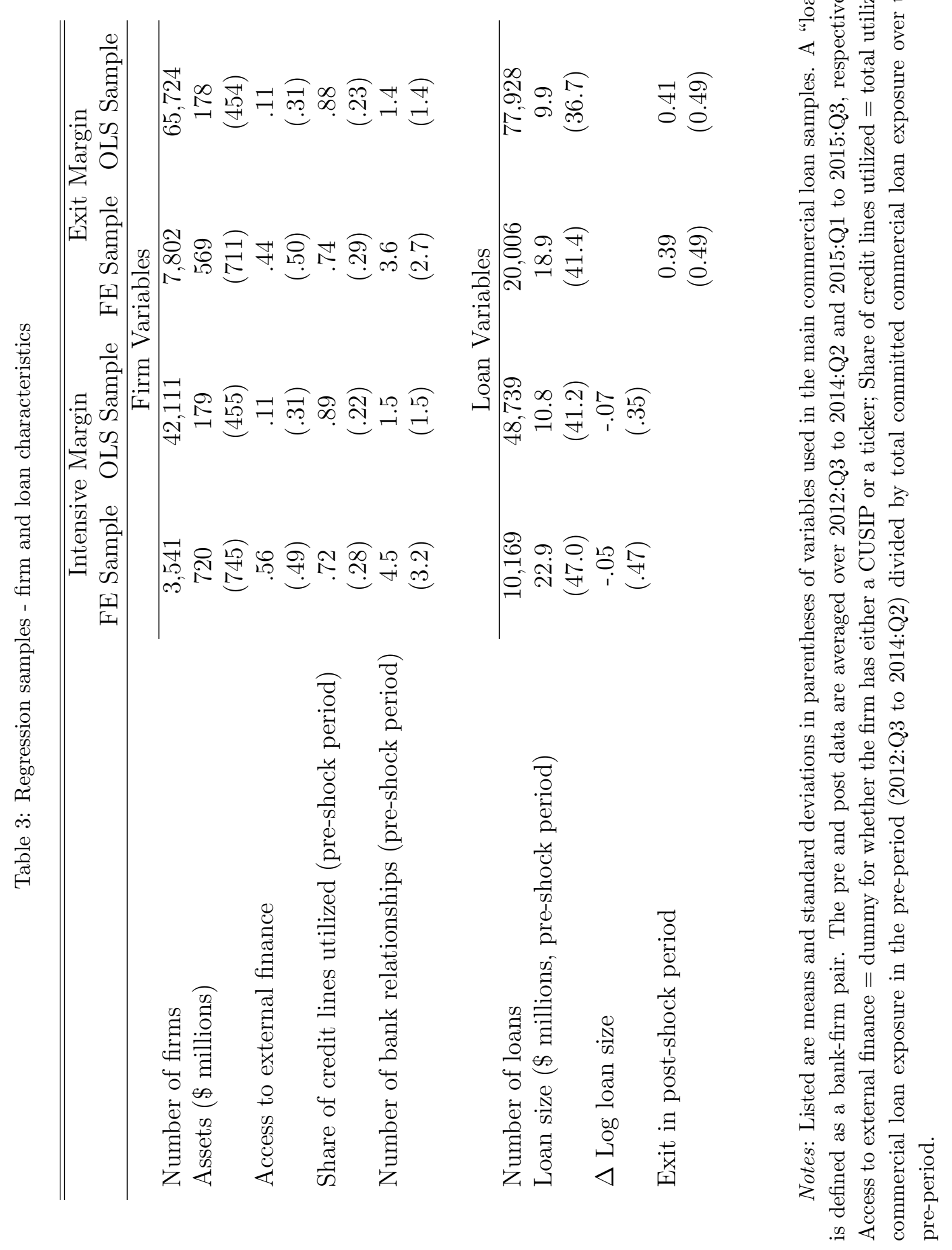


Table 4: The bank lending channel - commercial loans, intensive margin

$\begin{array}{lcccc}\text { O\&G Exposure } & -0.713^{* * *} & -0.824^{* * *} & -0.586^{* * *} & -0.326^{* * *} \\ & (0.248) & (0.162) & (0.172) & (0.059) \\ \text { Log Total Assets } & 0.057^{* * *} & 0.060^{* * *} & 0.043^{* * *} & 0.035^{* * *} \\ & (0.011) & (0.009) & (0.009) & (0.004) \\ \text { ROA } & -13.676^{* * *} & -14.124^{* * *} & -7.346^{* *} & -7.446^{* * *} \\ & (4.338) & (4.001) & (3.746) & (1.426) \\ \text { Equity/Total Assets } & -1.236^{* *} & -1.299^{* * *} & -0.421 & -0.999^{* * *} \\ & (0.544) & (0.488) & (0.555) & (0.136) \\ \text { Lag } \Delta \text { Log Commercial Loans } & -0.044 & -0.055 & -0.043 & -0.009 \\ & (0.047) & (0.040) & (0.031) & (0.016) \\ \text { NPL/Total Assets } & -4.098 & -4.522^{* *} & -3.940^{* *} & -1.859^{* *} \\ & (2.508) & (2.223) & (1.780) & (0.749) \\ \text { Tier-1 Capital/RWA } & 1.041 & 1.144 & 0.484 & 1.327^{* * *} \\ & (0.794) & (0.731) & (0.679) & (0.204) \\ \text { Total Loans/Total Assets } & 0.433^{* * *} & 0.456^{* * *} & 0.221^{* *} & 0.209^{* * *} \\ & (0.132) & (0.116) & (0.108) & (0.041) \\ \text { Charge Offs/Total Loans } & -6.836^{* * *} & -7.113^{* * *} & -3.213^{* * *} & -1.908^{* * *} \\ & (1.578) & (1.442) & (1.213) & (0.733) \\ \text { Commercial Loans/Total Loans } & -0.576^{* * *} & -0.617^{* * *} & -0.504^{* * *} & -0.312^{* * *} \\ & (0.142) & (0.116) & (0.106) & (0.043) \\ \text { Residential Loans/Total Loans } & -0.652^{* * *} & -0.714^{* * *} & -0.566^{* * *} & -0.514^{* * *} \\ & (0.230) & (0.181) & (0.169) & (0.055) \\ \text { Deposits/Total Liabilities } & 0.117^{* *} & 0.123^{* *} & 0.108^{* *} & 0.151^{* * *} \\ & (0.049) & (0.048) & (0.048) & (0.028) \\ \text { Foreign Bank Dummy } & 0.214^{* * *} & 0.230^{* * *} & 0.182^{* * *} & 0.145^{* * *} \\ & (0.049) & (0.038) & (0.034) & (0.013) \\ \text { Number of Observations } & 10162 & 10162 & 10162 & 48739 \\ \text { R-squared } & 0.59 & 0.59 & 0.18 & 0.06 \\ \text { Fixed Effects } & \text { Firm } & \text { Firm } & \text { Firm Controls } & \text { Firm Controls } \\ \text { Instrument } & \text { Branch Share } & & & \\ & & & & \end{array}$

Notes: The dependent variable is the change in log term-loan size. All quarterly data for a given loan were collapsed to a single pre and post period, defined as 2012:Q3 to 2014:Q2 and 2015:Q1 to 2015:Q3, respectively. We removed from the sample loans to firms in the oil and gas industry and data was restricted to term loans for consecutive quarters throughout both the pre- and post period (i.e., no exiting and reentering). O\&G exposure is constructed as total committed loans to O\&G firms divided by total committed commercial loans in 2012 and 2013. Column 1 is estimated under IV, where O\&G exposure is instrumented by the share of the BHC's branches in 2009 in counties with any O\&G income. Columns 1 and 2 are run on the sample of firms that borrow term loans from multiple banks and include firm fixed effects. Column 3 is run on the same sample of firms as columns 1 and 2 (but excluding firms in the O\&G industry) and includes firm controls instead of firm fixed effects. Column 4 includes firms that borrow from single banks and includes firm controls. All bank controls listed are measured in the pre-shock period. Firm controls in columns 3 and 4 include industry-times-region fixed effects (across 322 industries-3-digit NAICS codes, and 9 regions - the first digit of firm's zip code) and a dummy indicating whether the firm borrows from multiple banks. Standard errors in parentheses are two-way clustered at the bank (28 banks in total) and firm level. ${ }^{*} p<0.10,{ }^{* *} p<0.05,{ }^{* * *} p<0.01$. 


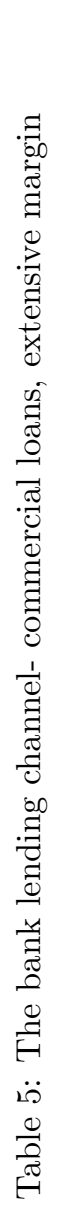

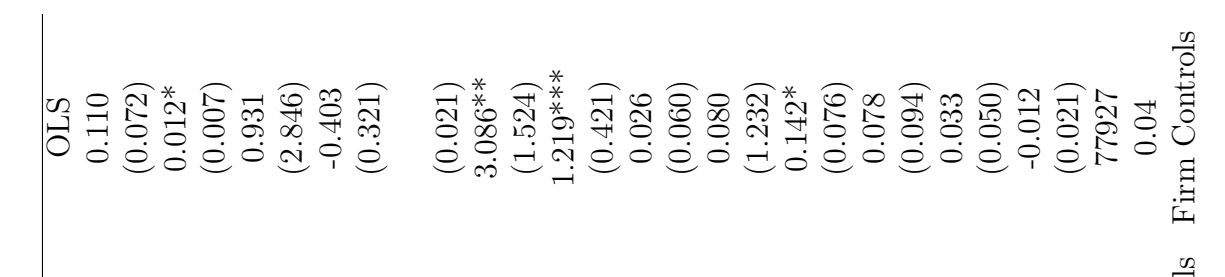



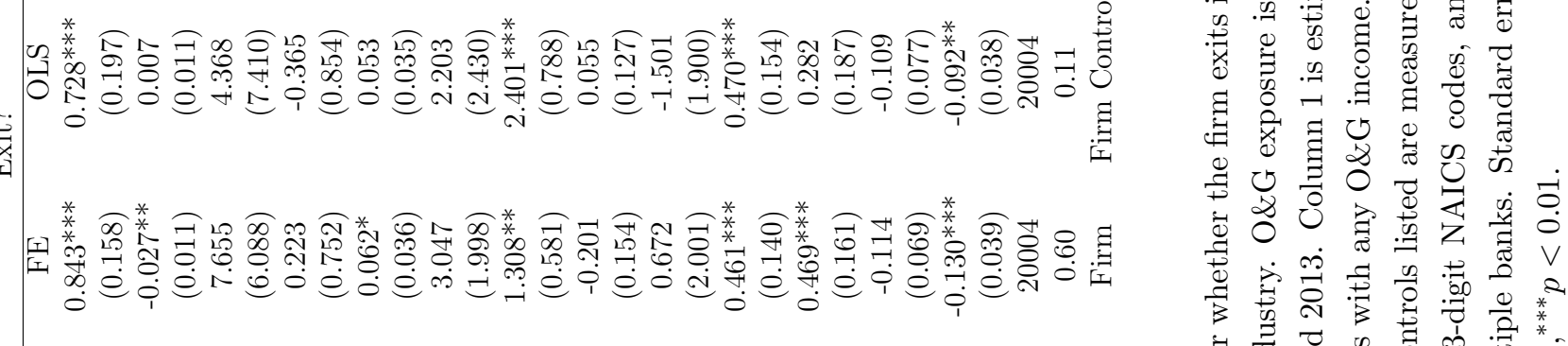

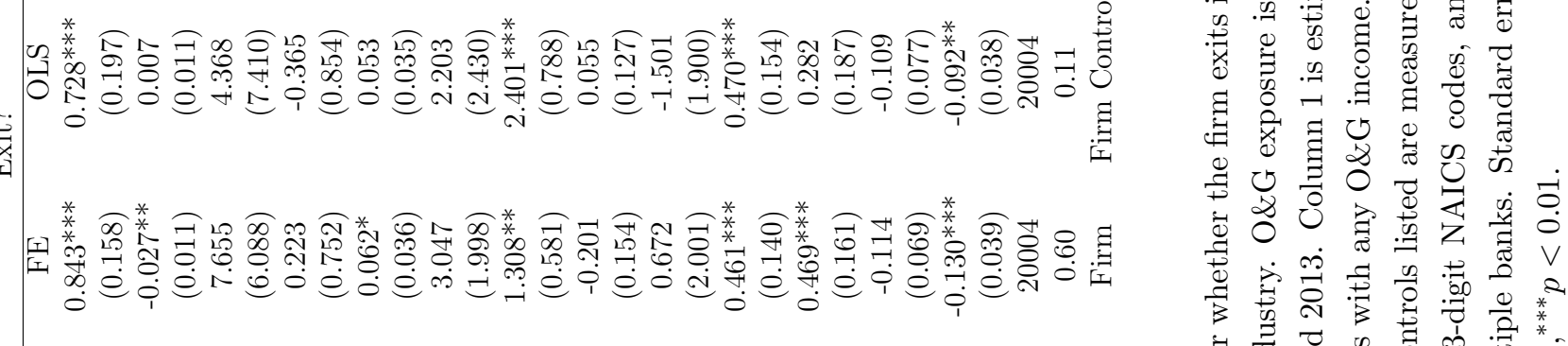

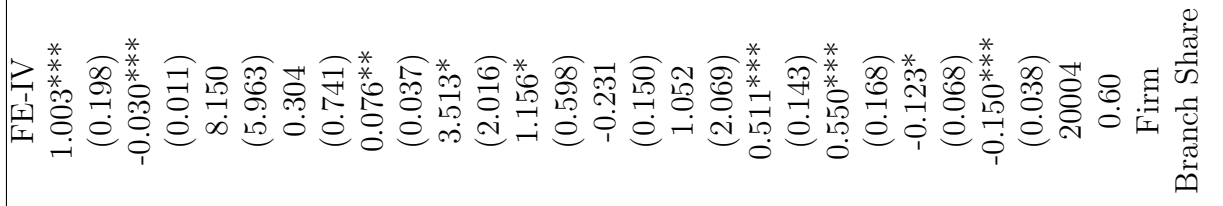

声.

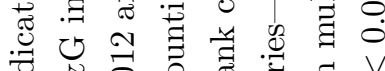

:

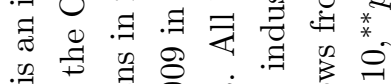

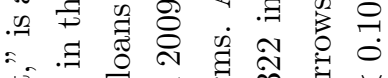

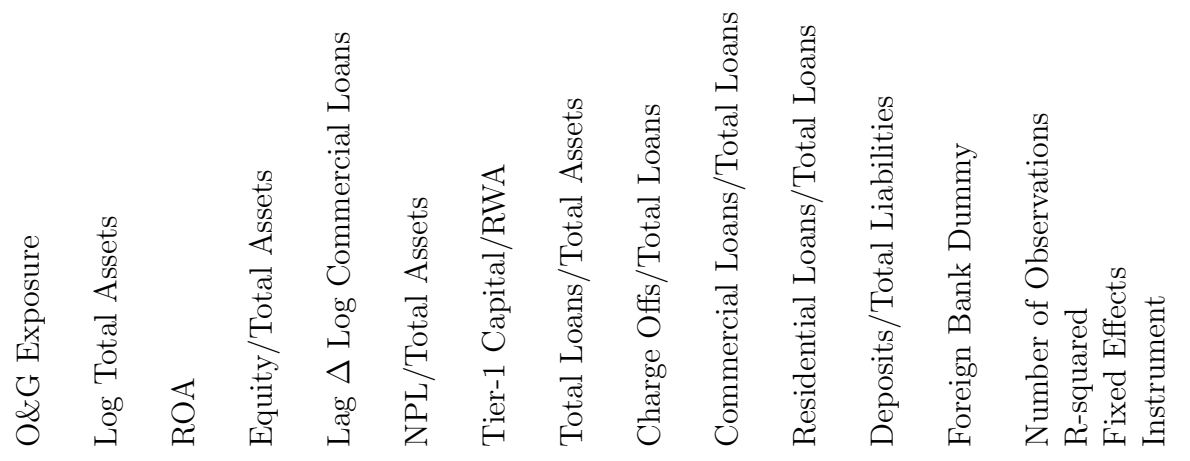

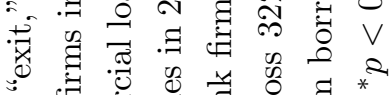

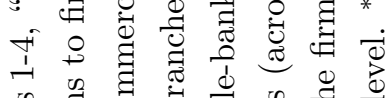

ज :

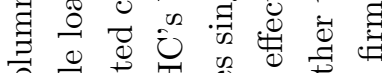

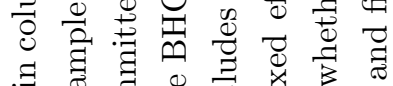

品

褐

సี

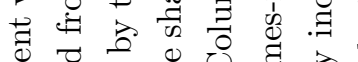

ర్ర

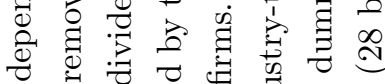

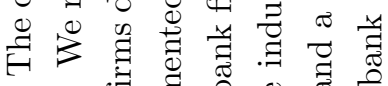

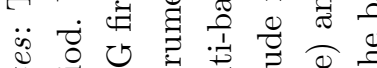




Table 6: The bank lending channel - commercial loans, interaction effects

O\&G Exposure

O\&G Exposure*External Finance Firm

External Finance Firm

O\&G Exposure*(Pre-period \# of Bank Relationships)

Pre-period \# of Bank Relationships

O\&G Exposure*(Pre-period Utilization Rate)

Pre-period Utilization Rate

Number of Observations

R-squared

Fixed Effects

\begin{tabular}{cc|cc}
\multicolumn{2}{c}{ Intensive Margin } & \multicolumn{2}{c}{ Exit? } \\
\hline $\mathrm{FE}$ & OLS & $\mathrm{FE}$ & OLS \\
$-1.105^{* *}$ & -0.137 & $1.023^{* *}$ & 0.310 \\
$(0.480)$ & $(0.361)$ & $(0.428)$ & $(0.311)$ \\
0.044 & 0.126 & 0.047 & 0.255 \\
$(0.245)$ & $(0.131)$ & $(0.298)$ & $(0.336)$ \\
& -0.002 & & $-0.033^{*}$ \\
& $(0.011)$ & & $(0.019)$ \\
-0.016 & -0.025 & 0.042 & $0.056^{* *}$ \\
$(0.026)$ & $(0.033)$ & $(0.026)$ & $(0.027)$ \\
& $0.008^{* * *}$ & & $-0.024^{* * *}$ \\
& $(0.003)$ & & $(0.002)$ \\
0.515 & -0.136 & -0.668 & -0.363 \\
$(0.480)$ & $(0.348)$ & $(0.423)$ & $(0.337)$ \\
& $-0.092^{* * *}$ & & $-0.154^{* * *}$ \\
10162 & $(0.023)$ & & $(0.023)$ \\
0.59 & 48739 & 20004 & 77927 \\
Firm & 0.06 & 0.60 & 0.05 \\
& Firm Controls & Firm & Firm Controls
\end{tabular}

Notes: The dependent variable for columns 1 and 2 is the change in log term-loan size and for columns 3 and 4 is an indicator whether the firm exits its banking relationship in the post-shock period (i.e., "exit."). All quarterly data for a given term loan were collapsed to a single pre- and post-shock period, defined as 2012:Q3 to 2014:Q2 and 2015:Q1 to 2015:Q3, respectively. We removed from the sample loans to firms in the O\&G industry. Data for the FE regressions were restricted to term loans in the sample for consecutive quarters throughout both the pre- and post-shock period (i.e., no exiting and re-entering). O\&G exposure is constructed as total committed loans to oil and gas firms divided by total committed commercial loans in 2012 and 2013. Columns 1 and 3 are run on the sample of firms with term loans from multiple banks and include firm fixed effects. OLS regressions include firms that borrow from single banks and includes firm controls. Firm controls include industry-times-region fixed effects (across 322 industries - 3-digit NAICS codes, and 9 regions - the first digit of firm's zip code) and a dummy indicating whether the firm borrows from multiple banks. External finance firm = dummy for whether the firm has either a CUSIP or a ticker; pre-period utilization rate $=$ total utilized commercial loan exposure in the pre-period (2012:Q3 to 2014:Q2) divided by total committed commercial loan exposure over the pre-period; pre-period \# of banks = number of banks the firm has at least one loan with in the pre-shock period; length of relationship = years between date of first origination and 2014:Q2. Bank controls include pre-shock period ROA, equity/total assets, NPL/total assets, tier-1 capital/risk-weighted assets, total loans/total assets, charge offs/total loans, commercial loans/total loans, residential loans/total loans, deposits/total liabilities, lag change in log commercial loans (defined between 2012:Q3 and 2014:Q2), and a foreign bank dummy. Standard errors in parentheses are two-way clustered at the bank and firm level (28 banks in total). ${ }^{*} p<0.10,{ }^{* *} p<0.05,{ }^{* * *} p<0.01$. 
Table 7: The credit channel - firm regressions

\begin{tabular}{lcc|ccc} 
& \multicolumn{2}{c}{ Y14 } & \multicolumn{3}{c}{ Y14 \& Compustat } \\
& Term Loans & All Loans & Liab & Eqty & Assets \\
\cline { 2 - 6 } Agg O\&G Exposure & 0.056 & 0.044 & -0.181 & -0.332 & 0.243 \\
Constant & $(0.066)$ & $(0.074)$ & $(0.499)$ & $(0.614)$ & $(0.435)$ \\
& 0.147 & $0.523^{* * *}$ & -0.062 & -0.821 & -0.249 \\
Number of Observations & $(0.136)$ & $(0.153)$ & $(0.647)$ & $(0.767)$ & $(0.500)$ \\
R-squared & 47208 & 47191 & 1466 & 1435 & 1466 \\
Bank Controls & 0.06 & 0.07 & 0.40 & 0.38 & 0.41 \\
Firm Controls & Yes & Yes & Yes & Yes & Yes \\
& Yes & Yes & Yes & Yes & Yes
\end{tabular}

Notes: These regressions are run at the firm level. We removed from the sample loans to firms in the O\&G industry. The dependent variable is the change in log total term-loan borrowing (column 1), the change in log total-loan borrowing (column 2), the change in log total liabilities (column 3), the change in log total equity (column 4), and the change in log total assets (column 5) by firm across the pre- and post-shock period. Total term loan borrowing includes all term loans across all banks in the Y14 sample. Total-loan borrowing includes utilized loans of all types (i.e., not just term loans) across all banks in the Y14 sample. Liabilities, equity, and assets are taken from Compustat, limiting the sample of firms. All quarterly data for a given loan were collapsed to a single pre and post period, defined as 2012:Q3 to 2014:Q2 and 2015:Q1 to 2015:Q3, respectively. Firm controls include industry-times-region fixed effects (across 322 industries - 3-digit NAICS codes, and 9 regions - the first digit of firm's zip code) and a dummy indicating whether the firm borrows from multiple banks. Agg-exposure is the loan-size weighted O\&G exposure across all banks by the firm. Bank controls include pre-shock period loan-weighted average levels of ROA, equity/total assets, NPL/total assets, tier-1 capital/risk-weighted assets, total loans/total assets, charge offs/total loans, commercial loans/total loans, residential loans/total loans, deposits/total liabilities, lag change in log commercial loans (defined between 2012:Q3 and 2014:Q2), and a foreign bank dummy. Robust standard errors in parentheses. ${ }^{*} p<0.10,{ }^{* *} p<0.05,{ }^{* * *} p<0.01$. 
Table 8: Substitute financing - alternative banks

\section{O\&G Exposure}

Agg O\&G Exposure

Number of Observations

R-squared

Fixed Effects

Bank Controls

\begin{tabular}{cccc|c}
\multicolumn{5}{c}{ Entry? } \\
\hline FE & FE & FE & FE & OLS \\
$-0.523^{* *}$ & 0.292 & $-0.346^{*}$ & 0.417 & \\
$(0.246)$ & $(0.200)$ & $(0.182)$ & $(0.268)$ & \\
& & & & $0.089^{* * *}$ \\
& & & & $(0.020)$ \\
7285 & 8437 & 12011 & 5118 & \\
0.41 & 0.42 & 0.36 & 0.63 & \\
Firm & Firm & Firm & Firm & Firm Controls \\
Yes & Yes & Yes & Yes & Yes
\end{tabular}

Notes: Fixed-effects (FE) regressions are run at the loan level. The dependent variable of the FE regressions is an indicator if the term loan was made for the first time in the post-shock period (i.e., entry). All FE regressions are run with multiple banking relationships using firm fixed effects. Column 1 is run on the sample of firms that exited from at least one banking relationship in the post period. Column 2 is run on the sample of firms that did not exit any banking relationship. Column 3 is run on a sample firms with at least one loan that declined in size. Column 4 is run on a sample of firms without any loans that decreased in size. Bank controls include pre-shock period ROA, equity/total assets, NPL/total assets, tier1 capital/RWA, total loans/total assets, charge offs/total loans, commercial loans/total loans, residential loans/total loans, deposits/total liabilities, lag change in log commercial loans (defined between 2012:Q3 and 2014:Q2), and a foreign bank dummy. Column 5 is a regression run at the firm level, where the dependent variable is a dummy equal to one if the firm exited at least one banking relationship and entered at least one banking relationship between the pre- and post-shock period. Bank controls are loan-size weighted in the OLS specification. We removed from the sample loans to firms in the O\&G industry. Standard errors in parentheses are two-way clustered at the bank (28 banks in total) and firm level for FE regressions and robust standard errors reported for the OLS regression. ${ }^{*} p<0.10,{ }^{* *} p<0.05,{ }^{* * *} p<0.01$. 
Table 9: The bank lending channel - residential loans

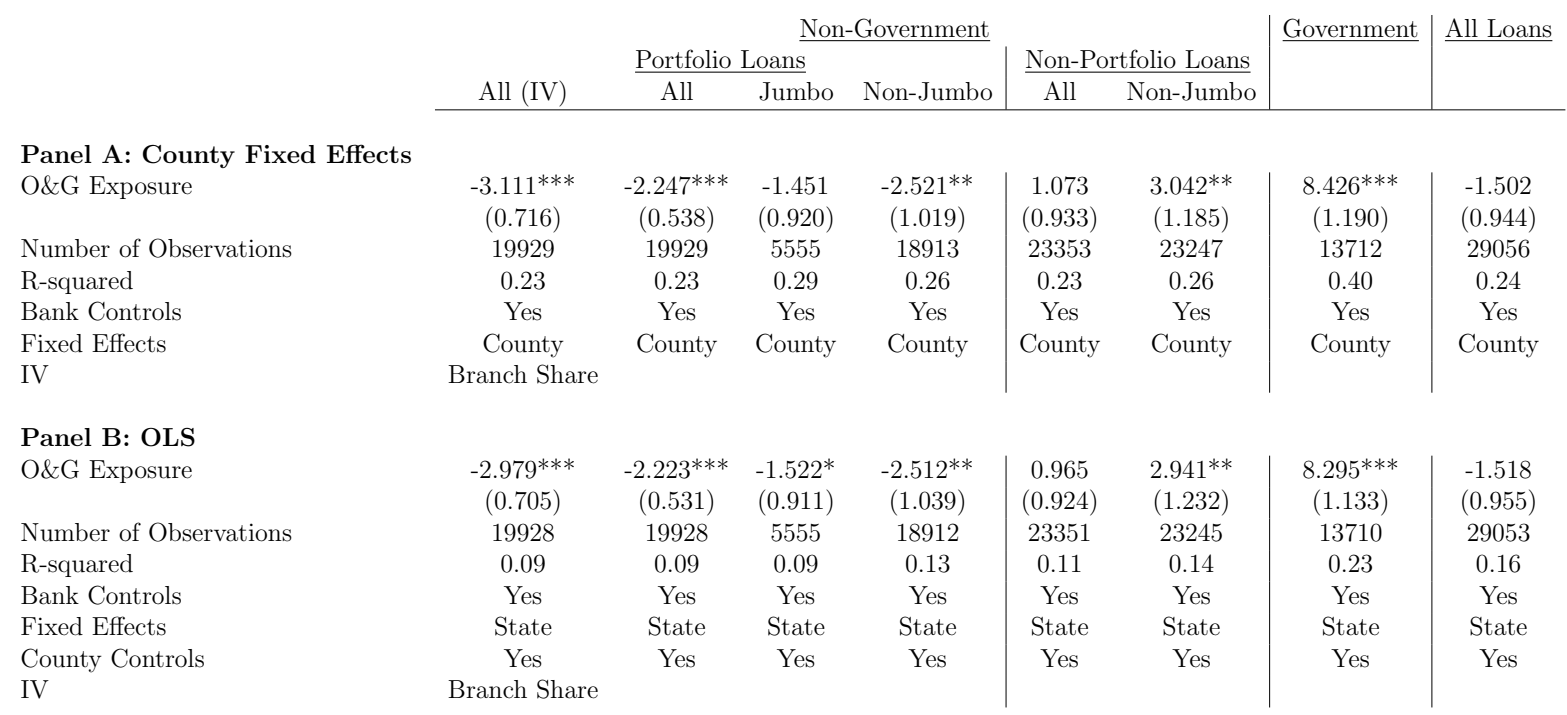

Notes: The dependent variable is the change in log residential loans by bank-county. All quarterly data for loans was aggregated by bank-county and then collapsed to a single pre- and post-shock period, defined as 2012:Q3 to 2014:Q2 and 2015:Q1 to 2015:Q3, respectively. O\&G exposure is constructed as total committed loans to oil and gas firms divided by total committed commercial loans in 2012 and 2013. Column 1 is estimated under IV, where O\&G exposure is instrumented by the share of the BHC's branches in 2009 in counties with any $\mathrm{O} \& \mathrm{G}$ income. Portfolio loans are divided between non-government jumbo loans, non-government non-jumbo loans, and government loans (i.e., FHA and VA loans). We include only loans originated by the BHC (i.e., we removed mortgages with loan source marked as correspondent, servicing rights purchased, and bulk purchased). Bank controls include pre-shock period ROA, equity/total assets, NPL/total assets, tier-1 capital/RWA, total loans/total assets, charge offs/total loans, commercial loans/total loans, residential loans/total loans, deposits/total liabilities, lag change in log residential loan (defined between 2012:Q3 and 2014:Q2), lag change in log MBS (defined between 2012:Q3 and 2014:Q2), and a foreign bank dummy. County controls include pre-period log population, log population density, percent veterans, log housing density, percent urban housing units, percent occupied housing units, percent vacant housing units, log median house value, $\log$ median rental value, fraction of housing with 3 or more individuals, percent in poverty, unemployment rate, percent disabled, log median household income. Standard errors in parentheses are two-way clustered at the bank (26 banks in total) and county level. ${ }^{*} p<0.10,{ }^{* *} p<0.05,{ }^{* * *} p<0.01$. 
Table 10: The credit channel - county regressions

\begin{tabular}{lc|c|c} 
& \multicolumn{2}{c|}{$\underline{\text { Y-14 }}$} & $\underline{\text { LPS }}$ \\
\cline { 2 - 3 } Aggregate O\&G Exposure & -0.477 & -0.263 & -0.105 \\
& $(0.901)$ & $(0.428)$ & $(0.532)$ \\
Number of Observations & 2951 & 3010 & 3003 \\
R-squared & 0.15 & 0.10 & 0.08 \\
Bank Controls & Yes & Yes & Yes \\
Fixed Effects & State & State & State \\
County Controls & Yes & Yes & Yes
\end{tabular}

Notes: The dependent variable is the change in log residential loans by county. All quarterly data for loans were aggregated by county and then collapsed to a single pre- and post-shock period, defined as 2012:Q3 to 2014:Q2 and 2015:Q1 to 2015:Q3, respectively. In column 1, we include only portfolio loans, and in column 2 all Y14 mortgages. In column 3, we include all loans in the LPS McDash Analytics database. Agg-exposure is the loan weighted $\mathrm{O} \& \mathrm{G}$ exposure across all banks in the county. Bank controls include pre-shock period (weighted to county level) ROA, ROE, NPL/total assets, tier-1 capital/RWA, total loans/total assets, charge offs/total loans, commercial loans/total loans, residential loans/total loans, deposits/total liabilities, lag change in log residential loan (defined between 2012:Q3 and 2014:Q2), lag change in log MBS (defined between 2012:Q3 and 2014:Q2), and a foreign bank dummy. County controls include pre-period log population, log population density, percent veterans, log housing density, percent urban housing units, percent occupied housing units, percent vacant housing units, log median house value, log median rental value, fraction of housing with 3 or more individuals, percent in poverty, unemployment rate, percent disabled, log median household income. Robust standard errors in parentheses. ${ }^{*} p<0.10,{ }^{* *} p<0.05,{ }^{* * *} p<0.01$. 
Table 11: The bank lending channel- instrumental variables

\begin{tabular}{|c|c|c|c|}
\hline & \multicolumn{3}{|c|}{ A: Commercial Loans } \\
\hline & $\begin{array}{c}\Delta \log \\
\text { loan size }\end{array}$ & Exit? & Entry? \\
\hline & FE-IV & FE-IV & FE-IV \\
\hline & \multicolumn{3}{|c|}{ Second Stage } \\
\hline \multirow[t]{2}{*}{$\Delta$ Log Market Cap } & $\begin{array}{c}0.901^{* * *} \\
(0.328)\end{array}$ & $\begin{array}{c}-0.953^{* *} \\
(0.410)\end{array}$ & $\begin{array}{c}0.056 \\
(0.209)\end{array}$ \\
\hline & \multicolumn{3}{|c|}{ First Stage } \\
\hline O\&G Exposure & $\begin{array}{c}-0.956^{* * *} \\
(0.368)\end{array}$ & $\begin{array}{c}-0.907^{* *} \\
(0.353)\end{array}$ & $\begin{array}{c}-0.907^{* *} \\
(0.367)\end{array}$ \\
\hline Number of Observations & 9719 & 19222 & 16412 \\
\hline R-squared (second-stage) & 0.60 & 0.61 & 0.57 \\
\hline Bank Controls & Yes & Yes & Yes \\
\hline Fixed Effects & Firm & Firm & Firm \\
\hline
\end{tabular}

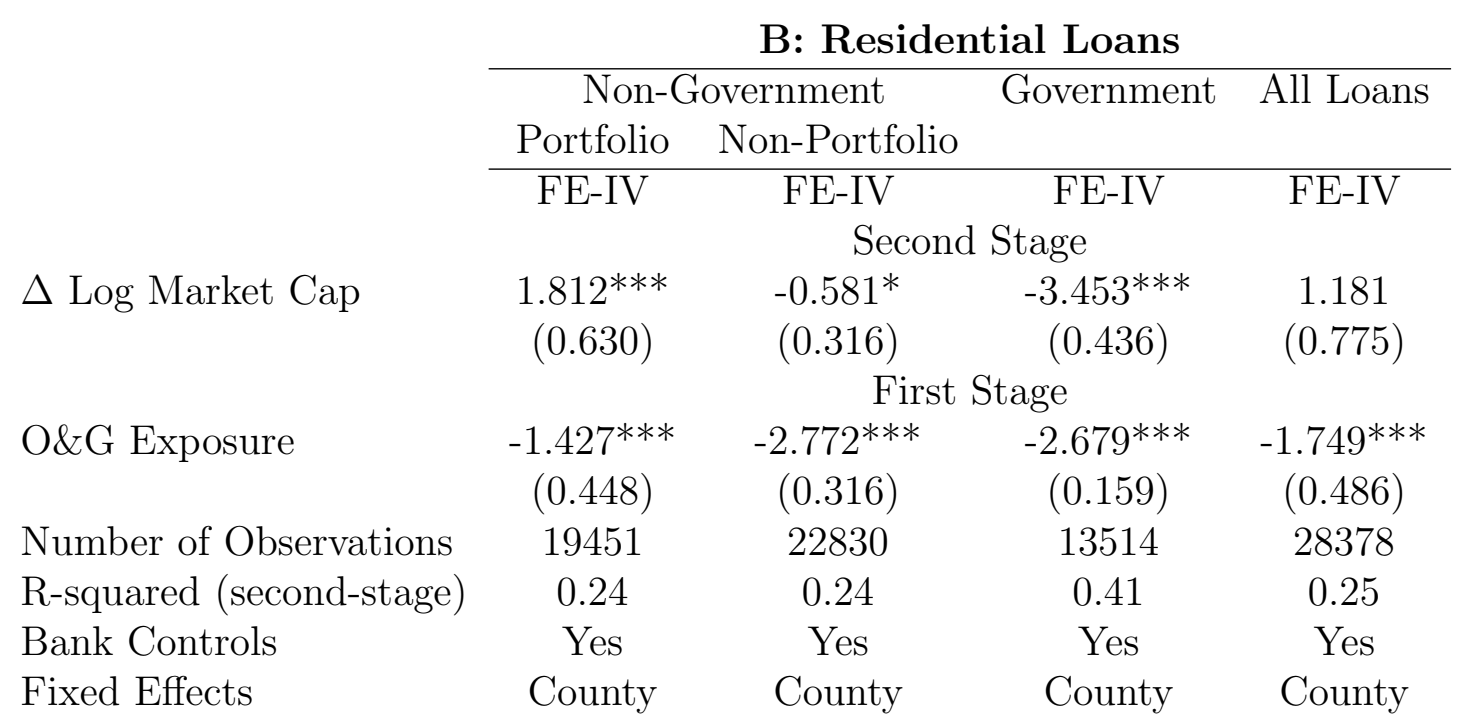

Notes: All regressions were run under two-stage least squares using O\&G exposure as an instrument for the change in bank's market capitalization - defined as the difference in log average quarterly market capitalization in the post-period (2015:Q1 and 2015:Q3) and pre-period (2012:Q3 and 2014:Q2). The dependent variables are the change in $\log$ term-loan size (column 1, panel A), an indicator whether the term loan is not renewed and the firm exits its banking relationship in the post period (column 2, panel A), and an indicator if the term loan was made for the first time in the post-period (column 3, pane A), and the change in $\log$ residential loans (originated by the BHC) by county and type of loan (panel B). Bank controls include pre-shock period ROA, equity/total assets, NPL/total assets, tier-1 capital/RWA, total loans/total assets, charge offs/total loans, commercial loans/total loans, residential loans/total loans, deposits/total liabilities, and a foreign bank dummy. Residential loan regressions in include the lag change in log residential loan (defined between 2012:Q3 and 2014:Q2) and lag change in log MBS (defined between 2012:Q3 and 2014:Q2) as controls, and the commercial loan regressions include the lag change in log commercial loans (defined between 2012:Q3 and 2014:Q2) as a control. Standard errors in parentheses are two-way clustered at the bank and firm level. ${ }^{*} p<0.10,{ }^{* *} p<0.05,{ }^{* * *} p<0.01$. 
Table 12: Robustness - alternative exposure measures

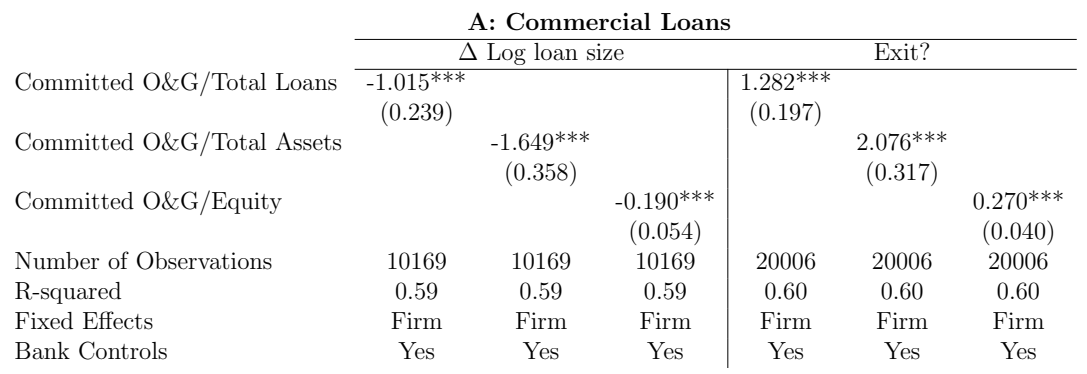

B: Residential Loans

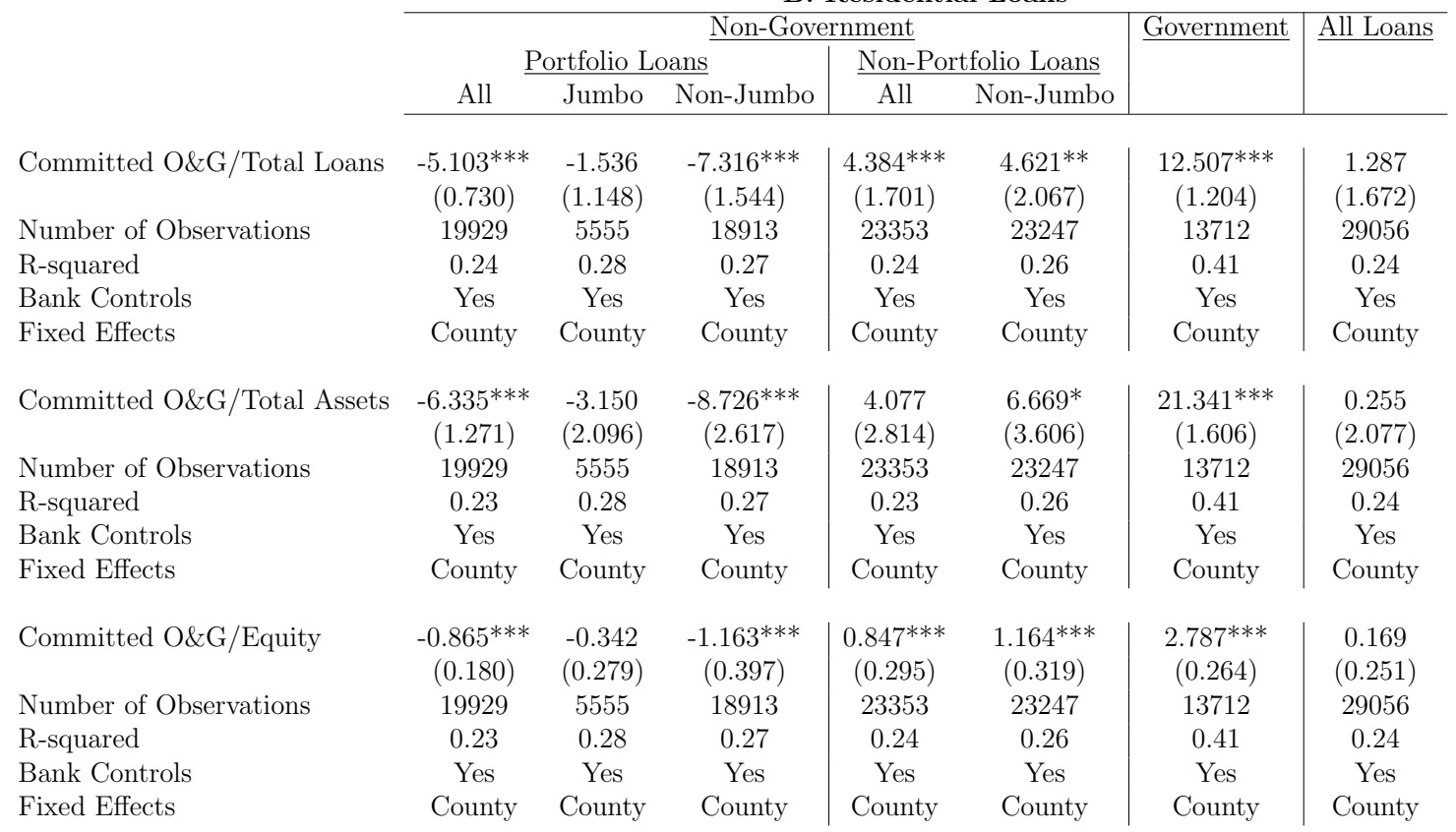

Notes: These tables show the main estimates under three alternative O\&G exposure variables: (1) committed O\&G commercial loans divided by total on-balance sheet loans, (2) committed O\&G commercial loans divided by total assets, and (3) committed O\&G commercial loans divided by total equity capital. The dependent variables are the change in log term-loan size (columns 1 and 2, panel A), an indicator whether the term loan is not renewed and the firm exits its banking relationship in the post period (columns 3 and 4, panel A), and the change in log residential loans (originated by the BHC) by county and type of loan (panel B). Bank controls include pre-shock period ROA, equity/total assets, NPL/total assets, tier1 capital/RWA, total loans/total assets, charge offs/total loans, commercial loans/total loans, residential loans/total loans, deposits/total liabilities, and a foreign bank dummy. Residential loan regressions in include the lag change in log residential loan (defined between 2012:Q3 and 2014:Q2) and lag change in log MBS (defined between 2012:Q3 and 2014:Q2) as controls, and the commercial loan regressions include the lag change in log commercial loans (defined between 2012:Q3 and 2014:Q2) as a control. Standard errors in parentheses are two-way clustered at the bank and firm level. ${ }^{*} p<0.10,{ }^{* *} p<0.05,{ }^{* * *} p<0.01$. Standard errors in parentheses are two-way clustered at the bank (28 banks in total) and firm level. ${ }^{*} p<0.10,{ }^{* *} p<$ $0.05,{ }^{* * *} p<0.01$. 
Table 13: Robustness -wild cluster bootstrap p-values

\begin{tabular}{lcc} 
A: Commercial Loans & $\begin{array}{c}\text { Commmited O\&G / } \\
\text { Committed C\&I Loans }\end{array}$ & $\begin{array}{c}\text { Commmited O\&G / } \\
\text { Equity }\end{array}$ \\
\hline$\Delta$ Log loan size & 0.006 & 0.059 \\
Exit? & 0.004 & 0.001 \\
B: Residential Loans & & \\
\hline Non-Government Portfolio Loans & 0.016 & 0.008 \\
$\quad$ Non-Government Portfolio (Jumbo) & 0.409 & 0.500 \\
$\quad$ Non-Government Portfolio (Non-Jumbo) & 0.074 & 0.022 \\
Non-Government Non-Portfolio & 0.466 & 0.081 \\
$\quad$ Non-Government Non-Portfolio (Non-Jumbo) & 0.301 & 0.145 \\
Government Loans & 0.053 & 0.008 \\
All Loans & 0.360 & 0.615
\end{tabular}

Notes: This table shows p-values of the coefficient on O\&G exposure constructed using the wild cluster bootstrap resampling method (clustered by bank) as described in Cameron and Miller (2015). The dependent variable is reported in column 1. Panel A shows p-values for the commercial loan regressions at the bank-firm level with firm fixed effects. Panel B shows p-values for the mortgage regressions at the bank-county level with county fixed effects. We report results under two measures of $O \& G$ exposure: committed O\&G loans divided by total committed C\&I loans (our main exposure variable, with coefficients reported in tables 4,5 , and 9) as well as committed O\&G loans divided by total equity (coefficients reported in table 12). 
Figure 1: Oil Prices, Problem Loans, and Credit-Line Utilization Rates

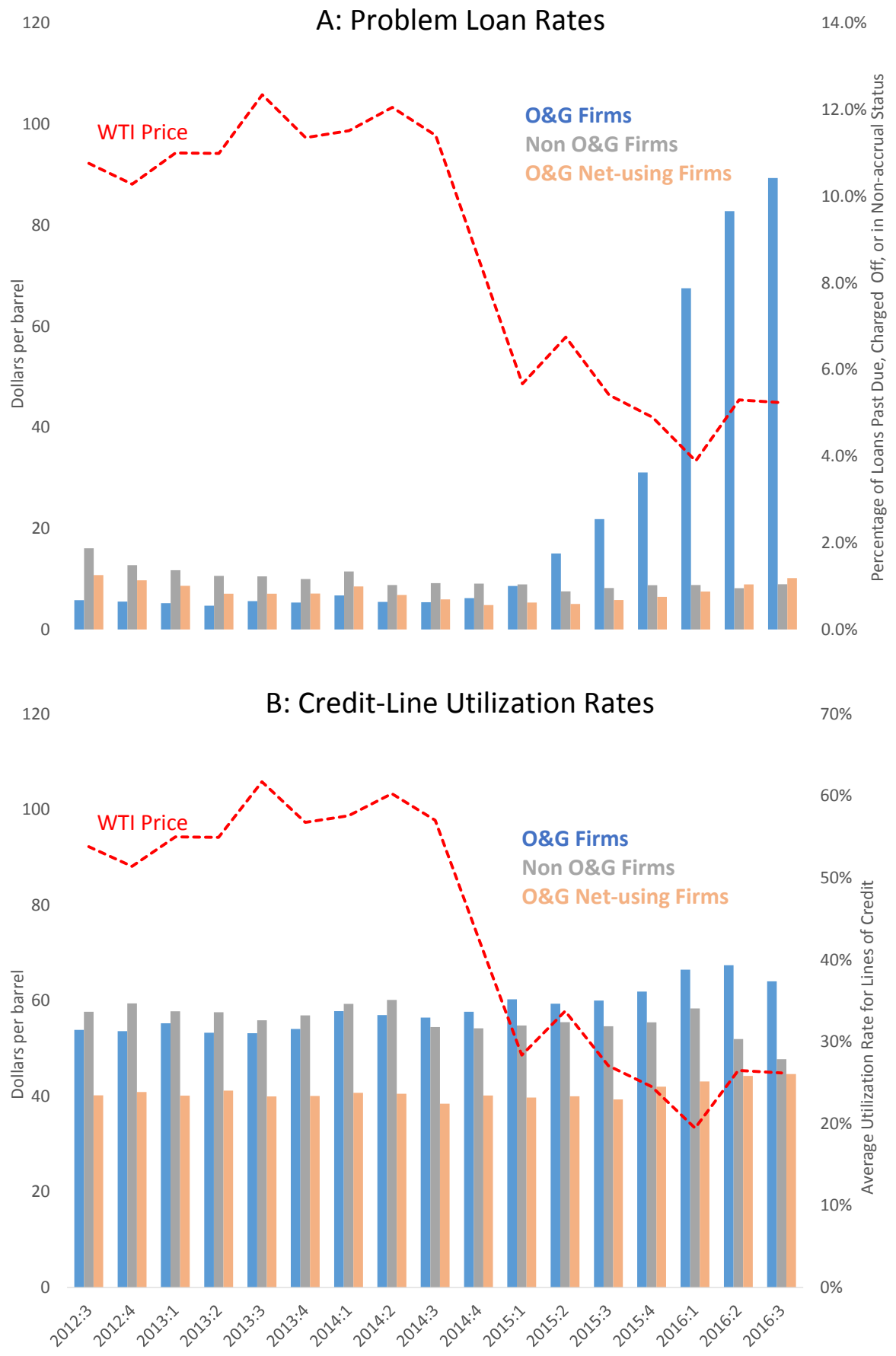

Notes: The red dashed line represents the price per barrel of crude West Texas Intermediate oil, collapsed to the quarterly level. Panel A: Blue bars represent the percentage of loans (i.e., including undrawn commitments) to oil and gas (O\&G) firms (defined by NAICS codes 211, 213111, and 213112) that are either past due, charged off, or in non-accrual status (referred to as "problem loans"). Gray bars represent the percentage of loans to all non-O\&G firms that are problem loans. Orange bars represent the percentage of loans to all net users of the O\&G industry - defined as firms in industries with less than - 0.10 in net trade (i.e., make minus use) with the O\&G industry, as defined by the 2007 BEA make and use tables - that are problem loans. Panel B: Blue bars represent the average utilization rate on a line of credit (defined as total utilized amount divided by total committed amount) to O\&G firms. Gray bars and orange bars represent the average utilization rate for non-O\&G and net users of the $O \& G$ industry. 
Figure 2: Net Trade with NAICS 324, 211, and 213111 as a Share of Total Output by Industry

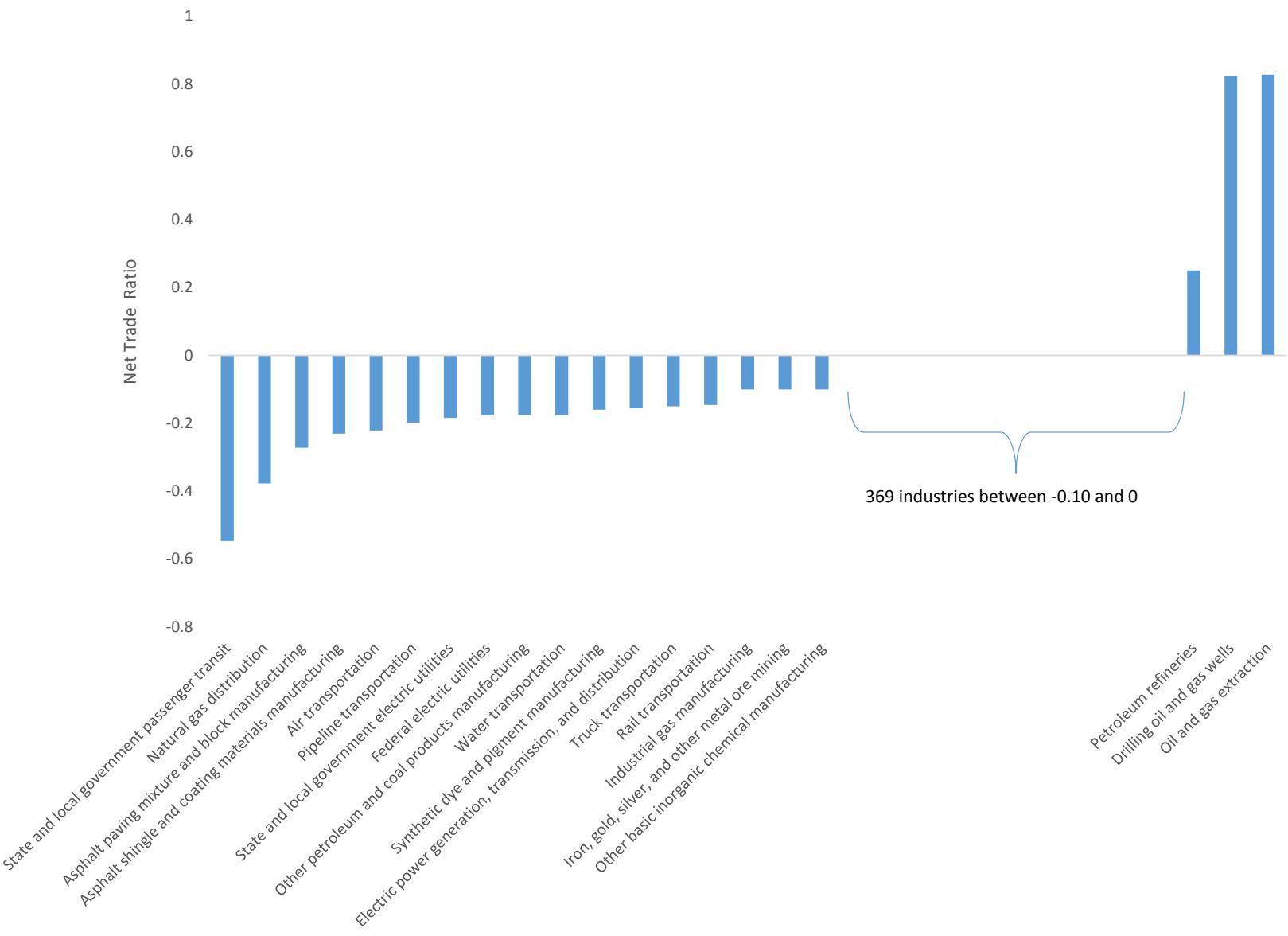

Notes: Bars represent net trade (that is, make minus use) of each industry with NAICS 324, 211, 213111 (petroleum refineries, oil and gas extraction, and drilling oil and gas wells, respectively), based on the 2007 Bureau of Economic Analysis (BEA) make and use tables (https://www.bea.gov/industry/io_annual. htm). BEA provides make and use matrix tables for 389 industries, where each industry is mapped into a three, four, or five digit NAICS code. NAICS code 213112 (support activities for oil and gas operations), included in our measure of oil and gas exposure, is not separately included in the BEA input-output table. We omit the (many) industries for which this net position is negligible. 
Figure 3: Stock price and market capitalization - dependence on oil exposure

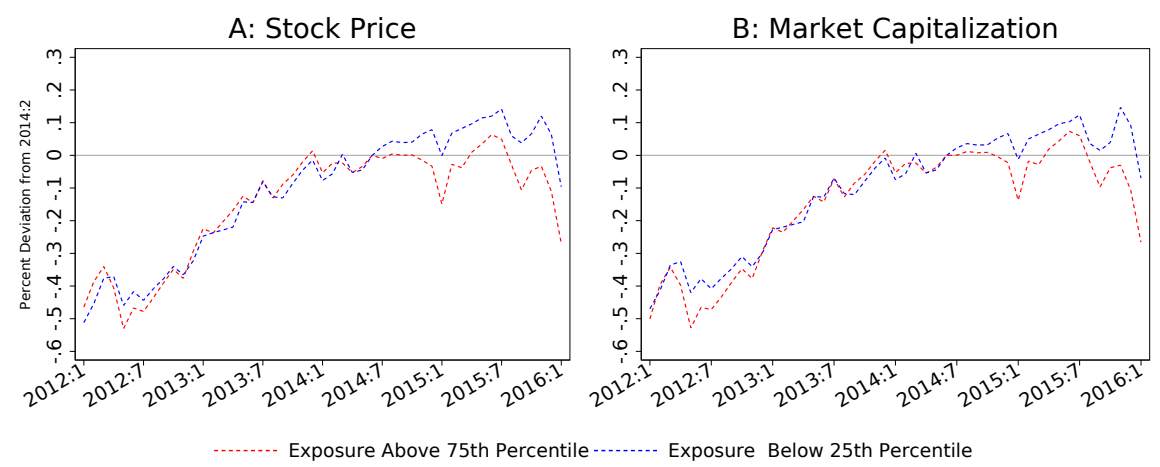

Notes: This figure illustrates the impact of a bank's oil and gas extraction (O\&G) exposure to bank stock prices (panel A) and market capitalization (panel B). For each bank in each month, we calculate the deviation of its stock price or market capitalization from 2014:M6. The red dashed line represents the average deviation for banks in the upper-quarter in terms of exposure to the O\&G sector, the blue dashed line represents the average deviation for banks in the bottom quartile.

Figure 4: Bank balance sheet variables - dependence on oil exposure

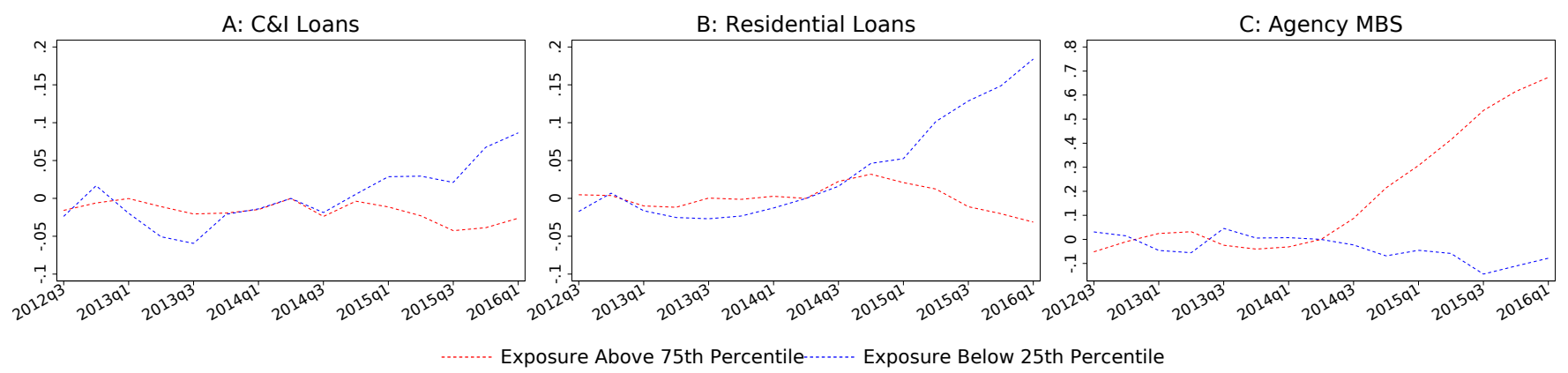

Notes: This figure illustrates the impact of a bank's oil and gas extraction (O\&G) exposure to commercial and industrial loans (C\&I), portfolio residential loans, and agency-backed MBS. All data are from the FRY9. For each bank, we regress the logarithm of the bank-level variable on a linear time trend over the pre-2014:Q2 sample. We collect the residuals and then normalize them by taking the difference relative to the 2014:Q2. We then sort banks into two groups - banks in the upper quartile (red-dashed line) and bottom quartile (blue-dashed line) O\&G exposure - and average for each group. 
Figure 5: Implied Coefficients on O\&G Exposure by Borrower Default Risk

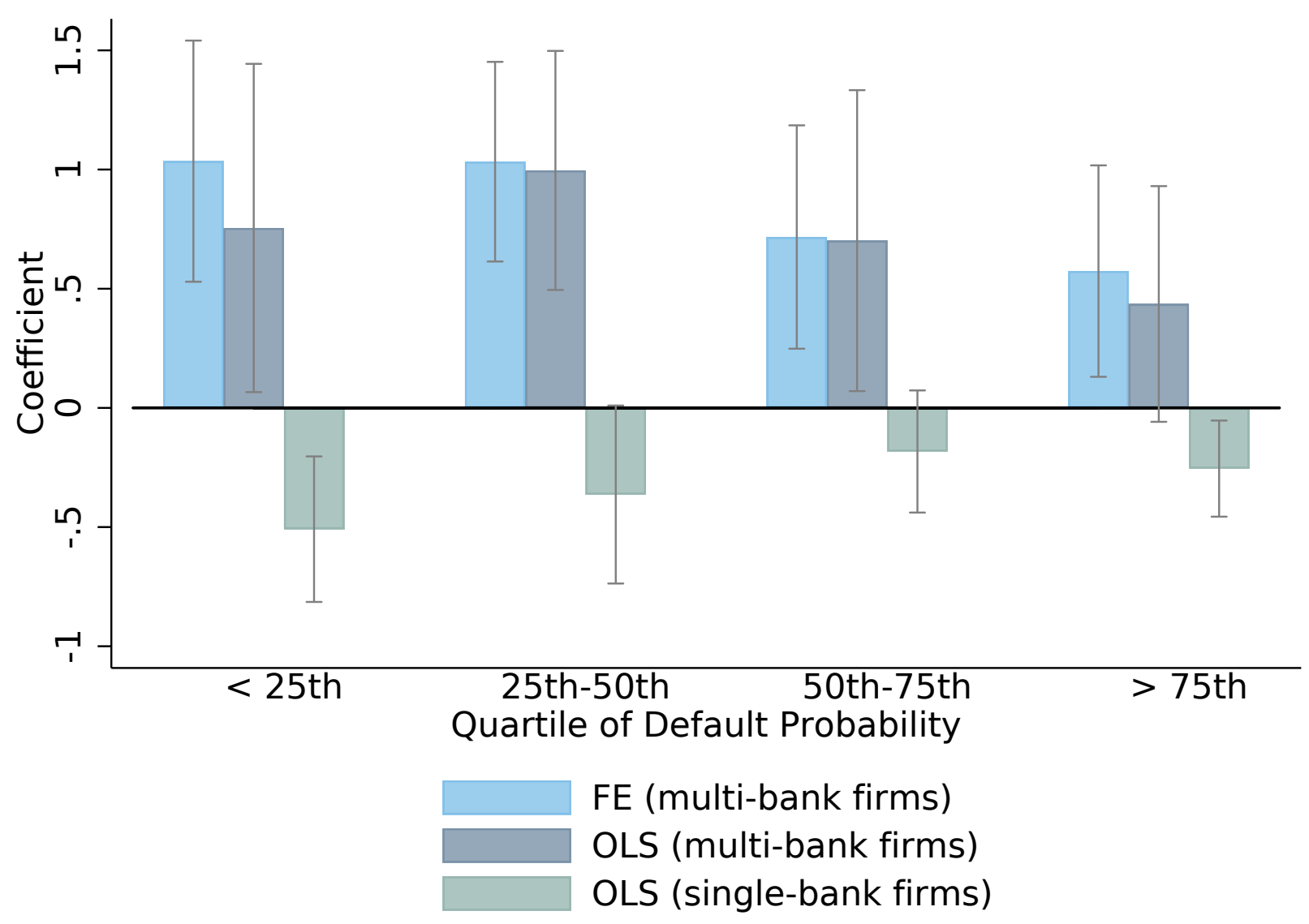

Notes: This figure plots estimates from the following regression: Exit $_{i j}=\beta_{j}+\beta_{1,1} Z_{i}+\beta_{1,2} Z_{i} * \mathbf{1}\left(\overline{P D}^{25 t h}<\right.$ $P D_{j}<\overline{P D}^{50 t h}+\beta_{1,3} Z_{i} * \mathbf{1}\left(\overline{P D}^{50 t h}<P D_{j}<\overline{P D}^{75 t h}\right)+\beta_{1,4} Z_{i} * \mathbf{1}\left(\overline{P D}^{75 t h}<P D_{j}\right)+\beta_{2} X_{i}+\varepsilon_{i j}$. "FE (multi-bank firms)" are estimates with firm-fixed effects over the sample of multi-bank firms. "OLS (multibank firms)" reports estimates where with industry-region controls on the sample of multi-bank firms. "OLS (multi-bank firms)" reports estimates with industry-region controls on the sample of single-bank firms. The first quartile reports $\hat{\beta}_{1,1}$, the second quartile reports $\hat{\beta}_{1,1}+\hat{\beta}_{1,2}$, the third quartile reports $\hat{\beta}_{1,1}+\hat{\beta}_{1,3}$, and the fourth quartile reports $\hat{\beta}_{1,1}+\hat{\beta}_{1,4}$ ) quartile firms, where standard errors are constructed using the delta method. 
Figure 6: Bank Lending Standards for Commercial Loans- dependence on oil exposure.

6

5



$-3$

6

B: Loan Rates

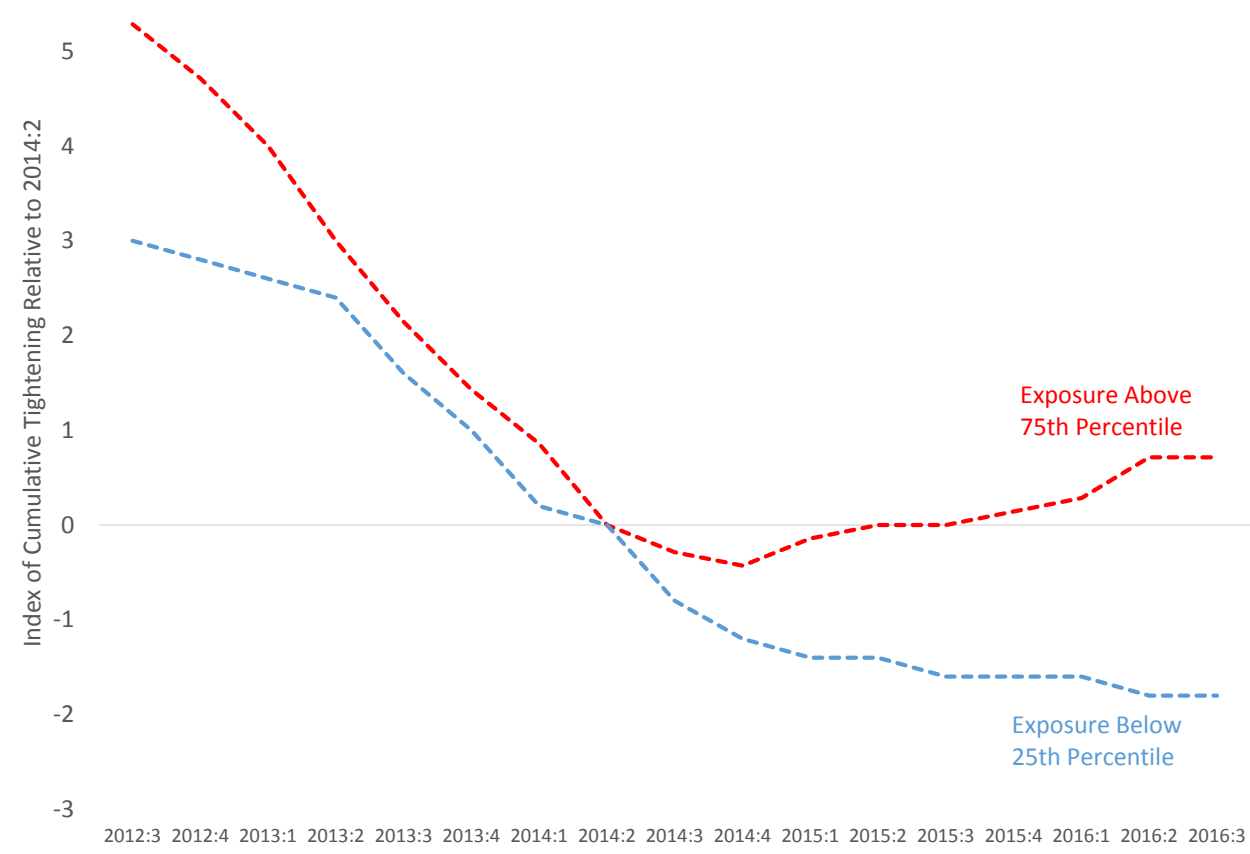

Notes: This figure illustrates the impact of a bank's oil and gas extraction (O\&G) exposure to banks lending standards for commercial loans. All data are from the Senior Loan Officer Opinion Survey (SLOOS). For each bank we measured the cumulative amount of survey responses in which the response was a tightening of the specified variable - loan covenants (panel A) or loan rates (panel B) - relative to 2014:Q2. The reddotted line represents the average for banks in the upper-quarter in terms of exposure to the O\&G sector, the blue-dotted line represents the average for banks in the bottom quartile. 
Figure 7: Bank Lending Standards for Mortgages- dependence on oil exposure.



Notes: This figure illustrates the impact of a bank's oil and gas extraction (O\&G) exposure to bank lending standards for mortgages. All data are from the Senior Loan Officer Opinion Survey (SLOOS) questions about qualifying mortgages. A positive slope indicates tightening. For each bank we measured the cumulative amount of survey responses in which the response was a tightening of the specified variable relative to 2015:Q1, the first date available. The GSE-eligible category of residential mortgages includes loans that meet the underwriting guidelines, including loan limit amounts, of the GSEs - Fannie Mae and Freddie Mac. The government category of residential mortgages includes loans that are insured by the Federal Housing Administration, guaranteed by the Department of Veterans Affairs, or originated under government programs, including the U.S. Department of Agriculture home loan programs. The non-jumbo, non-GSEeligible category of residential mortgages includes loans that satisfy the standards for a qualified mortgage and have loan balances that are below the loan limit amounts set by the GSEs but otherwise do not meet the GSE underwriting guidelines. The jumbo category of residential mortgages includes loans that satisfy the standards for a qualified mortgage but have loan balances that are above the loan limit amount set by the GSEs. The red dashed line represents the average for banks in the upper-quarter in terms of exposure to the O\&G sector, the blue dashed line represents the average for banks in the bottom quartile. 
Figure 8: Response of Average Risk Weight, Liquidity Ratio, Leverage Ratio, and Total Assets to Oil Shock
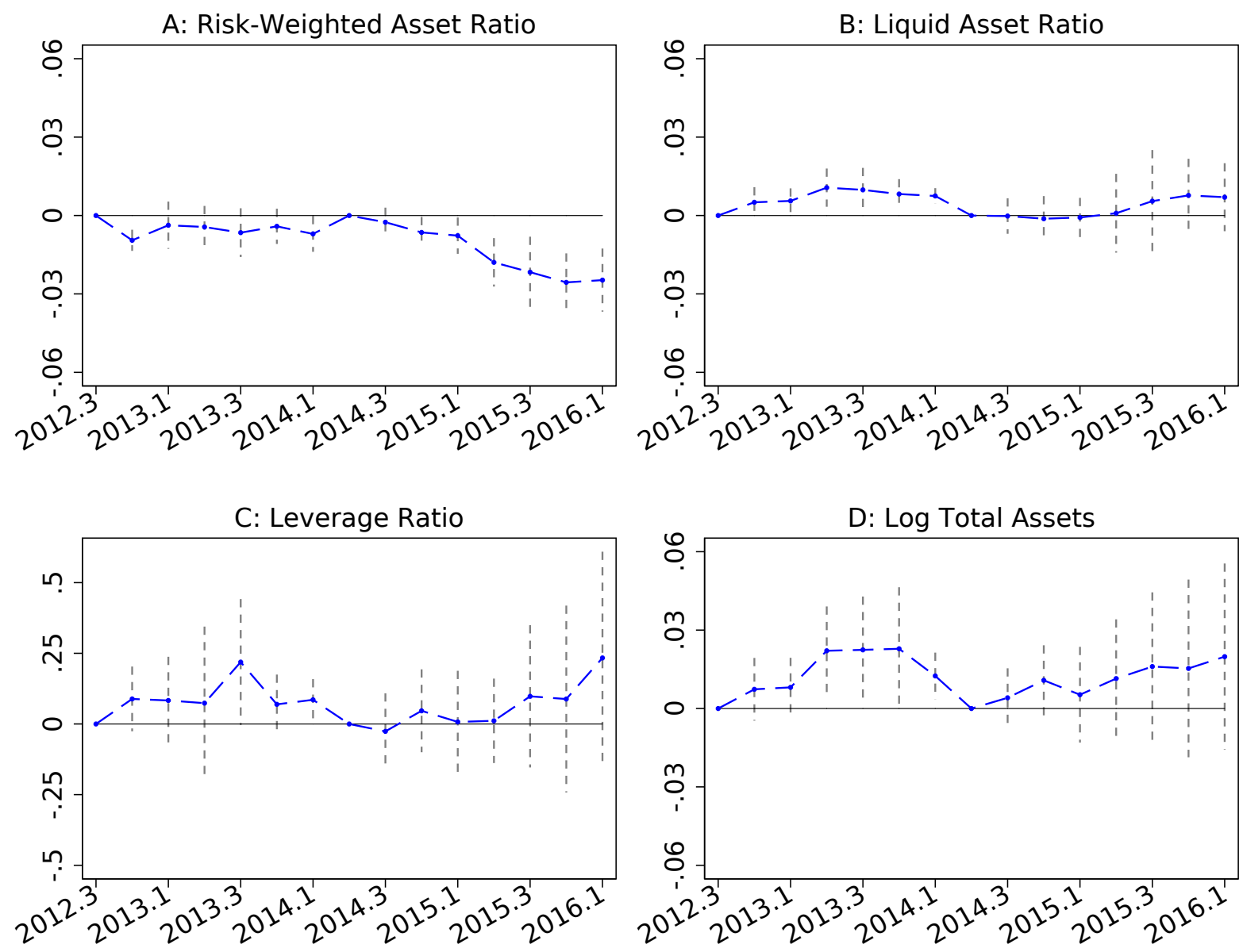

Notes: This figure illustrates the impact of a bank's oil and gas extraction (O\&G) exposure to the riskweighted asset ratio (total risk-weighted assets divided by total assets), the liquid asset ratio (defined as liquid assets divided by total assets), the leverage ratio (total assets divided by equity) and log total assets. Liquid assets are defined as cash holdings, U.S. Treasuries, U.S. government agency debt, and agency-backed MBS. All data are from the FR-Y9. We regress the logarithm of the bank-level variable on time dummies interacted with O\&G exposure, time dummies interacted with bank controls, time dummies, bank fixed effects, and bank-specific time trends. Shown are the coefficients and 95 percent confidence bands of the coefficients on the time dummies interacted with O\&G exposure. Omitted periods in the regression are 2012:Q3 and 2014:Q2, implying bank-specific time trends capture pre-shock period trends. Bank controls include pre-shock period loan-weighted average levels of ROA, equity/total assets, NPL/total assets, tier-1 capital/risk-weighted assets, total loans/total assets, charge offs/total loans, commercial loans/total loans, residential loans/total loans, deposits/total liabilities, and a foreign bank dummy. O\&G exposure was normalized to have a mean of one standard deviation. Standard errors are clustered by bank. To correct for a coding change in risk weights implemented by Basel III in 2015:Q1, the risk-weighted asset ratio (panel D) for 2015:Q1 for each bank was spliced with its 2014:Q4 value. 
Figure 9: Wild Cluster Bootstrap t-Statistic Permutation Test by Industry


Notes: This figure shows histograms of wild cluster bootstrap t-statistics for each of the 50 most common industries (defined by 3-digit NAICS code) in the commercial loan Y14 data. Analogous to the O\&G exposure variable used throughout this paper, for each of the other 49 industries we create a bank-specific exposure variable. We then run the fixed fixed-effects specification 50 times - once as our original specification, and 49 subsequent regressions, each time replacing O\&G exposure with one of the 49 other industry exposures. $t$ statistics for each regression were constructed using the wild cluster bootstrap resampling method (clustered by bank) as described in Cameron and Miller (2015). This sequence of steps was performed twice: producing two histograms, one for the intensive margin (Panel A) and one for the extensive margin (Panel B). The wild cluster bootstrap t-statistic for the O\&G exposure variable is marked in each panel. 


\section{Appendix A. Online Data Appendix}

In this appendix, we discuss our methods and assumptions involved in constructing the data set of commercial loan and mortgage loan observations from the Y-14 and Y-9 databases maintained by the Federal Reserve Board of Governors (FR). The disaggregated commercial and mortgage loans are obtained from the FR Y-14Q and FR Y-14M database, respectively.

\section{Appendix A.1. Commercial Loans}

Appendix A.1.1. Firm ID Cleaning

We use only loans made to U.S. firms. Firms are identified in Y14 by "tax identification number" (TIN), some of which had missing values. We used the field "obligorname" to help fill in those observations with missing TIN information or to identify potential problem TIN information. If an obligorname is associated with a missing TIN for some entry we look to see if, for an exact obligorname match, a TIN is provided anywhere else in the data set. ${ }^{46}$ If so, we fill in the missing TINS for that obligorname with the modal provided TIN.

We corrected the remainder of the missing TINS by the following:

- Standardize all obligornames using the STATA command stnd_command (Wasi and Flaaen (2015)).

- Flag "good TIN" - TINS uniquely associated with a standardized obligorname by a single bank.

- Replace missing TINS with matched (by standardized obligorname) good TIN.

- Replace remaining missing TINS with a newly created TIN assigned to standardized obligorname.

We then corrected TINs associated with more than one standardized obligorname. We replaced these TINS with a matched (by standardized obligorname) "good TIN." The remaining multipleobligorname TINs we replaced with a newly created TIN assigned by its standardized obligorname.

\section{Appendix A.1.2. Loan Level Cleaning}

We dropped loans if a duplicate loan ID ("internalcreditfacilityid") was found within a quarter. Any IDs that are inadvertently used by more than one bank were replaced with unique IDs.

We define term loans as those loans with credit facility type marked in the Y14 as "Term Loan," "Term Loan-A," "Term Loan-B," "Term Loan-C," "Term Loan-Bridge," "Term Loan-Asset Based," and "Term Loan-DIP."

We define loans as "Line of Credit" as those with facility type marked in the Y14 as "Revolving Credit," "Revolving Credit Converting to Term Loan," "Revolving Credit-Asset Based," "Revolving Credit-DIP," "Non-revolving Line of Credit," "Non-revolving Line of Credit Converting to Term Loan," and "Standby Letter of Credit."

\footnotetext{
${ }^{46}$ Obligorname was set to missing if individual, trust, confidential, NA etc.
} 
We then cleaned the above definitions via the following: We changed loans labeled as "Term Loan" in Y14 to "Line of Credit" if the loan had a zero interest rate and had any undrawn commitments over the life of loan - these are likely credit lines. We changed loans labeled as "Line of Credit" in Y14 to "Term Loan" if the loan had a non-zero interest rate and had no undrawn commitments over any part of the life of the loan - these are likely term loans.

\section{Appendix A.1.3. Industry Codes}

We focus on three-digit level NAICS codes. If multiple NAICS codes are used for a given TIN, we imposed the modal code. Some banks use SIC or GICS codes, which were converted to NAICS codes using a crosswalk.

NAICS code 211 (oil and gas extraction) was augmented with two six-digit codes 213111 (drilling oil and gas wells) and 213112 (support activities for oil and gas operations). To ensure that oil and gas extraction sector firms were labeled correctly we did the following sequence of steps.

- Flag suggestive obligornames names - those with any of the following words in the name "gas", "drill", "energy", "oil", "propane", "pipe", "power", "resource", "material", "petrol", "technologies", "operating."

- Assign firm to NAICS code 211 if at least 10 percent of its observations have NAICS code 211 and obligorname features any of the suggestive energy related words above.

- Assign firm to 211 if at least 10 percent of its observations have a suggestive energy related obligorname and at least one entry has a NAICS code 211.

O\&G exposure bank level variable is then created.

\section{Appendix A.1.4. Final Cleaning}

The Y14 imposes a $\$ 1 \mathrm{~m}$ materiality threshold from 2012:Q2 onwards. To allow for inflation and strategic behavior around the threshold, we left a buffer thus dropping those loans less than $\$ 1.2 \mathrm{~m}$. We dropped those observations still missing a TIN. We keep data between 2012:Q3 and 2015:Q3 - data before 2012:Q3 include 19 BHCs. Log loan change variables are then created.

\section{Appendix A.2. Residential Loans}

A 10 percent random sample was drawn from the Y-14M. We dropped loans with missing zip codes, origination amounts, and principal balance amounts. We then winsorized principal balances at the 1 percent level. All loans past due were dropped.

\section{Appendix A.2.1. Changes in Mortgage Loans}

Summary statistics of the log change in mortgage loans within a given county-bank pair between the pre- and post-shock period are shown in table A.14. The different categories of loans relate to different classes of mortgages meant to roughly mimic the broad categories included in SLOOS. 
Table A.14: Regression samples - residential loans

\begin{tabular}{lccc}
\hline \hline Variable & Observations & Mean & Std. Dev. \\
\hline Bank-County Level Variables & & & \\
$\Delta$ Log Total Loans & 32,832 & -0.18 & 0.54 \\
$\Delta$ Log Non-Government Portfolio Loans & 19,929 & -0.16 & 0.64 \\
$\Delta$ Log Non-Government Portfolio Jumbo Loans & 5,555 & 0.16 & 0.61 \\
$\Delta$ Log Non-Government Portfolio Non-Jumbo Loans & 18,913 & -0.12 & 0.67 \\
$\Delta$ Log Government Portfolio Loans & 3,639 & 0.02 & 0.87 \\
$\Delta$ Log Non-Government Non-Portfolio Loans & 24,366 & -0.09 & 0.52 \\
$\Delta$ Log Non-Government Non-Portfolio Non-Jumbo Loans & 22,892 & -0.06 & 0.55 \\
& & & \\
County Level Variables & & & \\
$\Delta$ Log Total LPS Loans & 2,938 & -0.11 & 0.14 \\
$\Delta$ Log Total Y-14 Loans & 2,943 & -0.16 & 0.12 \\
$\Delta$ Log Total Portfolio Y-14 Loans & 2,943 & -0.17 & 0.41
\end{tabular}

Notes: Listed are the summary statistics of dependent variables used in the residential loan regression analysis. For each category, we aggregate the data by county-bank-quarter, and then average over the preshock and post-shock periods (defined as 2012:Q3 to 2014:Q2 and 2015:Q1 to 2015:Q3, respectively), then take the difference of the log value. County-level variables are constructed in an analogous fashion at the county level.

\section{Appendix A.2.2. Defining Types of Mortgages}

Government, Portfolio, Non-Portfolio, and BHC origination categorization:

- Government Loans: Loan Type ( 1 = FHA Residential or 2 = VA Residential)

- Non-Government Portfolio Loans: Investor Type ( $7=$ Portfolio); Loan Type (NOT 1 = FHA Residential, NOT 2 = VA Residential)

- Non-Government Portfolio Loans Originated by BHC: Investor Type (7 = Portfolio); Loan Type (NOT 1 = FHA Residential, NOT 2 = VA Residential); Loan Source (NOT $3=$ Correspondent, NOT $4=$ Servicing Rights Purchased, NOT $5=$ Bulk Purchased)

- Non-Government Non-Portfolio Loans: Investor Type (NOT 7 = Portfolio); Loan Type (NOT $1=$ FHA Residential, NOT $2=$ VA Residential)

- Non-Government Non-Portfolio Loans Originated by BHC: Investor Type (NOT 7 = Portfolio); Loan Type (NOT 1 = FHA Residential, NOT 2 = VA Residential); Loan Source (NOT 3 = Correspondent, NOT $4=$ Servicing Rights Purchased, NOT $5=$ Bulk Purchased) 


\title{
Appendix B. Online Descriptive Appendix
}

\author{
Appendix B.1. OLS regressions
}

By comparing the OLS and FE estimators on the same sample we can assess the size of any bias induced by firm credit demand. In the second and third columns of table 4 we show the estimated OLS results using the same sample as our FE analysis (firms that borrow from multiple banks before and after the shock) and also on the much larger sample of loans (corresponding to 42, 111 firms instead of 3,541 ) of all firms who borrow from possibly only one bank, before and after. Details of the variables involved in the regressions are included in table 3. Within the same FE sample we see that the O\&G exposure coefficient is broadly similar $(-0.83$ in the FE specification compared to the -0.58 using OLS and firm controls), implying that the correlation of credit demand and supply is apparently not severely biasing the OLS coefficient. If anything, the correlation appears negative: firms that experience positive demand shocks appear more concentrated among banks that experienced negative supply shocks.

Thus, there is the suggestion that endogeneity bias, if there is any, may be towards attenuating the measured effect. In this case, and assuming any correlation between credit supply and demand effects is similar in the larger sample, we may expand our sample and treat the estimated OLS coefficients with reasonable confidence as a lower bound (in magnitude) on the credit supply effect. In this larger sample, we again obtain a highly statistically significant coefficient on O\&G exposure, although smaller in magnitude than the FE sample (-0.32). This suggests that the lending channel effect is weaker for single-relationship firms or, alternatively, that any effects of tightened credit are manifested in dimensions other than loan size.

\section{Appendix B.2. Adjusting the firm-level corporate regressions}

A way to correct for endogeneity bias in the firm-level OLS estimator entails directly comparing the FE and OLS estimates of the loan-level regressions for term loans and adjusting the initial aggregate OLS estimate accordingly (see Jimenez, Mian, Peydro, and Saurina Salas (2014)): ${ }^{47}$

$$
\hat{\beta}_{1}^{F}=\hat{\beta}_{1, O L S}^{F}-\left(\hat{\beta}_{1, O L S}-\hat{\beta}_{1, F E}\right) * \frac{\operatorname{Var}\left(Z_{i}\right)}{\operatorname{Var}\left(\bar{Z}_{i}\right)},
$$

where $\hat{\beta}_{1, O L S}, \hat{\beta}_{1, F E}$, and $\hat{\beta}_{1, O L S}^{F}$ are aggregate OLS, loan-level FE, and loan-level OLS estimates of the coefficient on O\&G exposure, respectively, and $\frac{\operatorname{Var}\left(Z_{i}\right)}{\operatorname{Var}\left(\bar{Z}_{i}\right)}$ represents the ratio of the in-sample variance of the loan-level and firm-level $O \& G$ exposure variables. Plugging in the coefficients from the intensive FE and OLS estimates gives a correction of -0.25 , generating a coefficient of -0.16 on the aggregate term-loan regression coefficient. ${ }^{48}$ Therefore, the bias-corrected coefficient is one-fifth

\footnotetext{
${ }^{47}$ Since our FE loan-level analysis dealt with term loans, this adjustment is not suitable for the other dependent variables in table 7 .

${ }^{48}$ From table $4, \hat{\beta}_{1, F E}=-0.83$ and $\hat{\beta}_{1, O L S}=-0.58$. The standard deviations of O\&G exposure in the OLS and FE aggregate regressions are both equal to 0.37 implying $\frac{\operatorname{Var}\left(Z_{i}\right)}{\operatorname{Var}\left(\bar{Z}_{i}\right)}=1$
} 
the size of the FE intensive effect $\left(=\frac{-0.16}{-0.83}\right)$ implying that firms were able to substitute 80 percent of the decline in loan supply simply from other Y14 banks.

The 80 percent number is likely a lower bound, for several reasons. First, even if there was not complete substitution for financing using funds from other Y14 banks, for some firms the shortfall was likely to be partly made up from loans from non-Y14 banks. Second, because firms' total change in term loans also includes extensive effects (where the bias is apparently less severe), using the coefficients on the intensive regressions likely implies an overcorrection. ${ }^{49}$ Finally, we note that the availability of commercial paper facilities and other modes of external finance reinforce the sense in which our adjusted estimate is only a bound.

\footnotetext{
${ }^{49}$ While one could combine both the intensive and extensive effects by implementing a Tobit model, a fixed effects Tobit estimator does not exist - there is no sufficient statistic allowing fixed effects to be conditioned out of the likelihood function. Including unconditional fixed effects is also not suitable, since it suffers from the incidental parameters problem and is biased. See Greene (2004).
} 


\section{Appendix C. Online Robustness Appendix}

Here we show the effects of including controls to the fixed-effects intensive and extensive regressions from commercial loans.

Table C.15: Commercial Loans - robustness of bank controls

\begin{tabular}{|c|c|c|c|c|c|c|c|c|c|c|}
\hline & & & $\Delta \log$ loan & Size & & & & Exit? & & \\
\hline & $\mathrm{FE}$ & $\mathrm{FE}$ & $\mathrm{FE}$ & $\mathrm{FE}$ & $\mathrm{FE}$ & $\mathrm{FE}$ & $\mathrm{FE}$ & $\mathrm{FE}$ & $\mathrm{FE}$ & $\mathrm{FE}$ \\
\hline O\&G Exposure & -0.134 & $-0.318^{* *}$ & $-0.296 *$ & $-0.365^{* *}$ & $-0.824 * * *$ & $0.325^{* *}$ & $0.419^{* *}$ & $0.454^{* *}$ & $0.531^{* * *}$ & $0.843^{* * *}$ \\
\hline & $(0.120)$ & $(0.141)$ & $(0.162)$ & $(0.160)$ & $(0.162)$ & $(0.143)$ & $(0.198)$ & $(0.199)$ & $(0.166)$ & $(0.158)$ \\
\hline Log Total Assets & & $0.015^{* *}$ & $0.017^{* * *}$ & $0.023^{* * *}$ & $0.060 * * *$ & & 0.000 & -0.000 & $-0.010^{*}$ & $-0.027^{* *}$ \\
\hline & & $(0.006)$ & $(0.006)$ & $(0.007)$ & $(0.009)$ & & $(0.004)$ & $(0.005)$ & $(0.005)$ & $(0.011)$ \\
\hline Lag $\Delta$ Log Commercial Loans & & $0.032^{*}$ & $0.031^{*}$ & $0.050^{* *}$ & -0.055 & & 0.033 & 0.025 & -0.027 & $0.062^{*}$ \\
\hline & & $(0.017)$ & $(0.017)$ & $(0.021)$ & $(0.040)$ & & $(0.020)$ & $(0.020)$ & $(0.024)$ & $(0.036)$ \\
\hline Foreign Bank Dummy & & $0.062^{* *}$ & $0.068^{* *}$ & $0.066^{* * *}$ & $0.230^{* * *}$ & & -0.022 & -0.030 & -0.030 & $-0.130 * * *$ \\
\hline & & $(0.029)$ & $(0.027)$ & $(0.023)$ & $(0.038)$ & & $(0.031)$ & $(0.032)$ & $(0.023)$ & $(0.039)$ \\
\hline $\mathrm{ROA}$ & & & 1.211 & 0.643 & $-14.124^{* * *}$ & & & $-6.845^{*}$ & -1.251 & 7.655 \\
\hline & & & $(3.603)$ & $(3.513)$ & $(4.001)$ & & & $(3.557)$ & $(3.725)$ & $(6.088)$ \\
\hline NPL/Total Assets & & & -0.818 & 0.118 & $-4.522 * *$ & & & 1.917 & -0.165 & 3.047 \\
\hline & & & $(1.726)$ & $(1.658)$ & $(2.223)$ & & & $(2.339)$ & $(1.929)$ & (1.998) \\
\hline Charge Offs/Total Loans & & & -1.646 & -1.624 & $-7.113^{* * *}$ & & & -1.609 & -2.662 & 0.672 \\
\hline & & & $(2.035)$ & $(1.632)$ & $(1.442)$ & & & $(2.539)$ & $(1.742)$ & $(2.001)$ \\
\hline Equity/Total Assets & & & & $0.684^{* *}$ & $-1.299 * * *$ & & & & $-0.818^{* *}$ & 0.223 \\
\hline & & & & $(0.334)$ & $(0.488)$ & & & & $(0.379)$ & $(0.752)$ \\
\hline Tier-1 Capital/RWA & & & & -0.741 & 1.144 & & & & $2.243^{* * *}$ & $1.308^{* *}$ \\
\hline & & & & $(0.589)$ & $(0.731)$ & & & & $(0.582)$ & $(0.581)$ \\
\hline Total Loans/Total Assets & & & & & $0.456^{* * *}$ & & & & & -0.201 \\
\hline & & & & & $(0.116)$ & & & & & $(0.154)$ \\
\hline Commercial Loans/Total Loans & & & & & $-0.617^{* * *}$ & & & & & $0.461^{* * *}$ \\
\hline & & & & & $(0.116)$ & & & & & $(0.140)$ \\
\hline Residential Loans/Total Loans & & & & & $-0.714^{* * *}$ & & & & & $0.469^{* * *}$ \\
\hline & & & & & $(0.181)$ & & & & & $(0.161)$ \\
\hline Deposits/Total Liabilities & & & & & $0.123^{* *}$ & & & & & -0.114 \\
\hline & & & & & $(0.0$ & & & & & $(0.069)$ \\
\hline Number of Observations & 10162 & 10162 & 10162 & 10162 & 10162 & 20004 & 20004 & 20004 & 20004 & 20004 \\
\hline R-squared & 0.59 & 0.59 & 0.59 & 0.59 & 0.59 & 0.60 & 0.60 & 0.60 & 0.60 & 0.60 \\
\hline Fixed Effects & Firm & Firm & Firm & Firm & Firm & Firm & Firm & Firm & Firm & Firm \\
\hline
\end{tabular}

Notes: The dependent variable is the change in log term-loan size (columns 1-5) and an indicator whether the term loan is not renewed and the firm exits its banking relationship in the post-shock period (columns 6-10). All quarterly data for a given loan were collapsed to a single pre and post period, defined as 2012:Q3 to 2014:Q2 and 2015:Q1 to 2015:Q3, respectively. We removed from the sample loans to firms in the oil and gas industry and data was restricted to term loans for consecutive quarters throughout both the preand post period (i.e., no exiting and re-entering). O\&G exposure is constructed as total committed loans to O\&G firms divided by total committed commercial loans in 2012 and 2013. All bank controls listed are measured in the pre-shock period. Standard errors in parentheses are two-way clustered at the bank (28 banks in total) and firm level. ${ }^{*} p<0.10,{ }^{* *} p<0.05,{ }^{* * *} p<0.01$. 